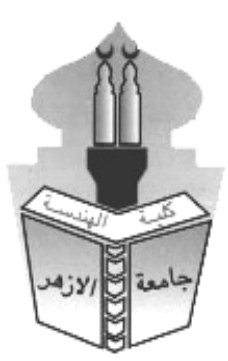

Vol.17, No. 62, January, 2022, 189-218

\title{
PUNCHING SHEAR BEHAVIOR OF ISOLATED FOOTING REINFORCED WITH GLASS FIBER REINFORCED POLYMER BARS Khaled A. Saleh ${ }^{1}$, Hadad Said Hadad ${ }^{2}$, and Mohammed Taha Nooman ${ }^{3}$
}

\footnotetext{
${ }^{1}$ Master Student, Civil Engineering Department, Faculty of Engineering, Al-Azhar University, Cairo, Egypt

${ }^{2}$ Professor, Institute of Concrete Research, Housing and Building National Research Center, Cairo, Egypt

${ }^{3}$ Associate Professor, Civil Engineering Department, Faculty of Engineering, Al-Azhar University, Cairo, Egypt
} Received :. 22 Sept.2021 Accepted:.20 Dec. 2021

\section{ABSTRACT}

GFRP bars are widely used as a substitute material to the traditional reinforcing steel in R. C sections, especially those exposed to destructive environmental agents. This current research aims to finding out the behaviour of R. C isolated footings reinforced with GFRP bars. To achieve the objective of this research, eight square footing were tested. The dimensions of the test specimens were chosen to be approximately equal to $(1 / 2-1 / 3)$ of the size of a common footings usually used in medium height buildings. The specimens were divided in two series. The first series included four footings (GF3 to GF6) that were reinforced with GFRP bars. For the comparison of the behaviour of R. C footing reinforced with GFRP bars with which reinforced with steel bars the second test series included four footings (SF3 to SF6) that were reinforced with steel bars. The test parameters investigated were the shear span-depth ratio $(\mathrm{a} / \mathrm{d})$ ranged between 3.46 and 4.23 the reinforcement bars type (GFRP and steel bars) and the reinforcement ratio $(0.5 \%$ and $1.0 \%)$. To present the effect of Soil-structure interaction all specimens were realistically supported on a sand bed. From the results, it can be found that the ultimate capacity of punching shear for footing specimens reinforced with GFRP bars was slightly similar to that for footing specimens reinforced with steel bars with a reduction ranged from 16 to $33 \%$. 
PUNCHING SHEAR BEHAVIOR OF ISOLATED FOOTING REINFORCED WITH GLASS FIBER REINFORCED POLYMER BARS

\section{Keywords:}

Isolated footings; glass fiber bars; FRP; failure mode; foundation; punching shear behavior
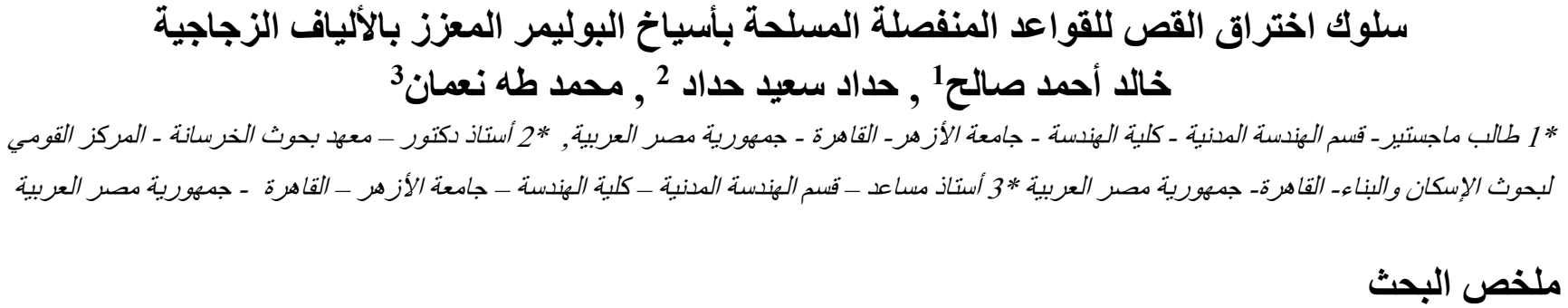

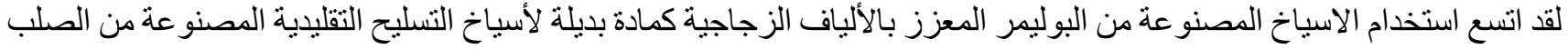

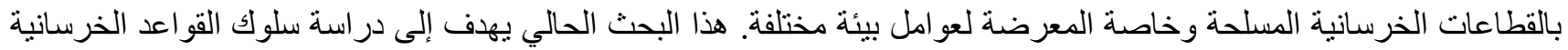

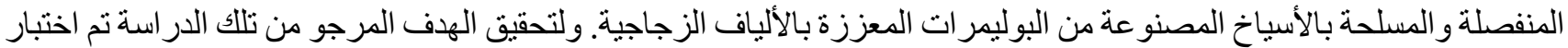

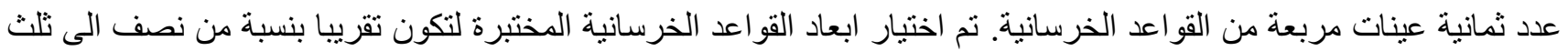

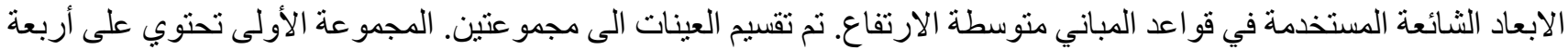

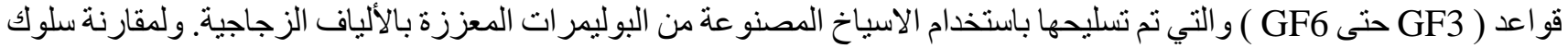

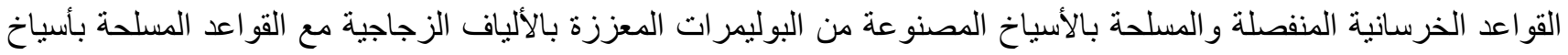

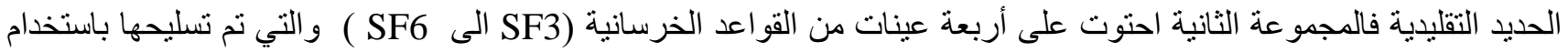

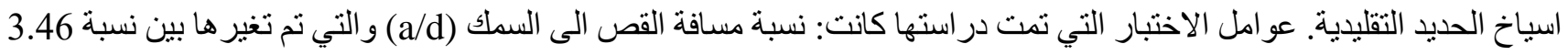

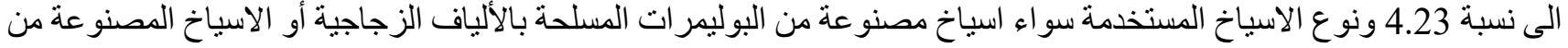

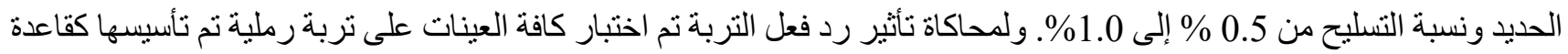

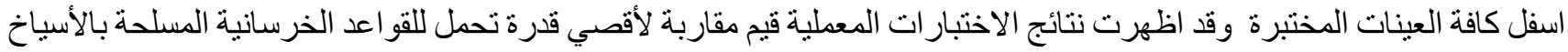

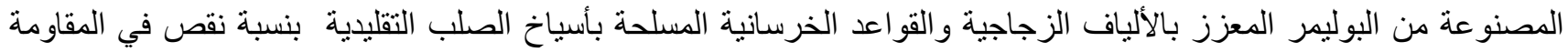

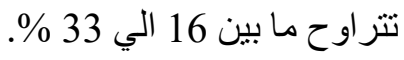

\section{INTRODUCTION}

The hardest challenge facing the use of traditional reinforced concrete in civil structures is overcoming the steel corrosion problem, which happens to the reinforcing steel bars. Steel reinforcement bars' corrosion in reinforced concrete elements exposed to extreme marine environments is attributed to the aggressive nature of chloride ions. When the steel reinforcement bars corrodes, its diameter decreases, and the severity of bars corrosion can affect significantly on the flexural strength, bond strength and mode of failure. That leads to a reduction in load - carrying capacity of R.C elements. Several solutions have been proposed by researchers for overcoming the corrosion problem such as using different kinds of steel reinforcing bars like epoxy-coated steel, stainless steel and galvanised steel, increasing the concrete cover and improving concrete quality. The high costs of repair and maintenance of structures damaged by corrosion led to develop a new concrete 
reinforcing material. In the last few decades, the utilization of FRP has increased dramatically in various engineering fields. With the high strength and corrosion resistance of the FRP bars, they represent a promising substitute to steel reinforcement in R. C structures. While foundation is that part of the structure, which is in direct contact with soil, they are exposed to aggressive environments more than any other element of the structure. In addition, it is so difficult to be repaired. Therefore, the using of FRP bars as a substitute concrete reinforcing material in the reinforced concrete footings has a great importance worth studding to improve the reinforced concrete structures performance and to limit the complicated and expensive prospective repair techniques.

\subsection{RESEARCH SIGNIFICANCE}

With the lack of test results related to R.C footings, an experimental examination including eight isolated steel and GFRP R.C footings was performed to enhance a better comprehension of the behavior of isolated GFRP RC footings. This investigation explores the behavior of R. C footings with FRP bars reinforcement in normal strength concrete. The test results of this current investigation compared with the predicted results, calculated according to a number of punching shear strength equations for FRP R.C contribution Vc established by different, organizations and researchers to contributes to the current knowledge of GFRP-RC footings and to the global experimental database of the behaviour of FRP R. C elements.

\subsection{PUNCHING SHEAR STRENGTH}

Footing analysis is based on theoretical and empirical equations such as those applied to floor slabs. Flat plate systems may exhibit two different types of shear failure depending on the type of loading (distributed load or concentrated load) and the geometry of the slab-column connections (column size, slab thickness the presence of column capitals). These two types are: One-way shear or beam action and Two-way shear or punching shear. In the one-way shear mechanism, the slab behaves as a wide rectangular beam the failure occurs at an inclined crack extending across the entire width of the slab. The behavior of beams subjected to shearing stresses can be divided into two stages: 1) pre-cracking behaviour and 2) post-cracking behaviour [1].There is a huge effort being made by researchers on the durability of FRP bars and to explore the behaviour of concrete elements reinforced with FRP. On the other hand, the information on the behavior of FRP R. C footings is relatively limited due to the lack of analytical and experimental studies. Only two researches available have studied the behaviour of FRP 
reinforced concrete footings by Mohammad P. Kivi et al. [2] and Asghar et al. [3]. The so-called shear failure is usually considered as one of the most critical structural failure modes for R.C structures, primarily for the structural members without shear reinforcement. Not at all like other failure types like flexural, practically no admonition happens, signalizing that the construction is at the beginning of failing in shear. Subsequently, structural members shear failures typically lead to catastrophic, loss of casualties and properties, and shall be forestalled at first and foremost [4].

A numerous of Punching Shear strength equations for FRP R.C contribution Vc established by different, organizations and researchers were selected and reviewed. Among them are:

1- ACI440.1R-15 [5]

$$
\begin{aligned}
& V_{c}=\left(\frac{4}{5} k\right) \sqrt{f^{\prime} c} \cdot u_{\mathrm{o}: 0.5 \mathrm{~d}} * d \quad \text { Eq. (1) } \\
& k=\sqrt{\left(\rho_{f} n_{f}\right)^{2}+2 \rho_{f} n_{f}}-\rho_{f} n_{f} \quad \text { Eq. (1b) } \\
& n_{f}=\frac{E_{f}}{E_{c}} \quad \text { Eq. (1c) }
\end{aligned}
$$

Where $\mathrm{k}$ : the axial stiffness factor for FRP reinforcement, $n_{f}$ : is modular ratio $E_{f}$ : is Young's modulus of FRP reinforcement; $E_{c}$ : is the concrete Young's modulus $d$ : is the effective depth $\rho_{f}$ : is the reinforcement ratio $=\frac{A_{f}}{b_{w} d}, b_{\mathrm{w}}$ : is the web width and $u_{\mathrm{o}: 0.5 \mathrm{~d}}$ : is the Peripheral length of the design cross - section at $d / 2$ from the loaded area.

2- CSA S806-12 design provisions [6]

$$
V_{c}=\text { min. of }\left\{\begin{array}{l}
0.028 \lambda \varphi_{c}\left(1+\frac{2}{\beta_{c}}\right) \sqrt[3]{E_{f u} p_{f} f^{\prime}{ }_{c}} u_{\mathrm{o}: 0.5 \mathrm{~d}} * d \\
0.147 \lambda \varphi_{c}\left(\frac{\alpha_{s} d}{u_{\mathrm{o}: 0.5 \mathrm{~d}}}+0.19\right) \sqrt[3]{E_{f u} p_{f} f^{\prime}} u_{c} u_{\mathrm{o}: 0.5 \mathrm{~d}} * d \quad \text { Eq.(2) } \\
0.056 \lambda \varphi_{c} \sqrt[3]{E_{f u} p_{f} f^{\prime}} u_{c: 0.5 \mathrm{~d}} * d
\end{array}\right.
$$

Where $\varphi c=0.6$ for concrete - cast - in - situ $\lambda=1.0$ for normal density concrete, $\beta \mathrm{c}$ : is the ratio of the long side to short side of the column concentrated load or reaction area, $\alpha \mathrm{s}=4$ for interior columns 3 for edge columns and 2 for corner columns Efu : Young's modulus of tensile reinforcement ; $\rho f$ : Reinforcement ratio defined as the average values for the reinforcement in both directions; and $\mathrm{f} c$ is the design compressive strength of concrete $(\mathrm{N} / \mathrm{mm} 2)$

\section{3- JSCE design recommendations [7]}

$$
V_{p c d}=\beta_{\mathrm{d}} \cdot \beta_{\mathrm{p}} \cdot \beta_{\mathrm{r}} f_{p c d} u_{\mathrm{p}} d / \gamma_{\mathrm{b}}
$$

Where

$$
f_{p c d}=0.2 \sqrt{f^{\prime} c d} \mathrm{~N} / \mathrm{mm}^{2} \text {, shall be } \leq 1.2 \mathrm{~N} / \mathrm{mm}^{2} \quad \text { Eq. (3a) }
$$




$$
\begin{array}{cc}
\beta_{d}=\sqrt[4]{(1 / d)} \leq 1.5(d: m) & \text { Eq. (3b) } \\
\beta_{p}=\sqrt[3]{100 \rho_{f} \cdot E_{f u} / E_{S}} \leq 1.5 & \text { Eq. (3c) } \\
\beta_{r}=1+\frac{1}{1+0.25 u / d} & \text { Eq. (3d) }
\end{array}
$$

$\mathrm{f}^{\prime} \mathrm{cd}$ : design compressive strength of concrete (N/mm2) , u_p: Peripheral length of the design cross - section at d/2 from the loaded area u: Peripheral length of loaded area, $E_{f u}$ : Young's modulus of tensile reinforcement E_S: Standard Young's modulus (= $200 \mathrm{kN} / \mathrm{mm} 2) d$ : Effective depth, $\rho_{f}:$ Reinforcement ratio, defined as the average values for the reinforcement in both directions and $\gamma_{b}$ : Generally, $=1.3$

4- A. W. El-Ghandour, K. Pilakoutas, and P. Waldron [8]

$$
V_{c}=0.33 \sqrt{f^{\prime} c}\left(\mathrm{E}_{f} / \mathrm{E}_{s}\right)^{1 / 3} b_{o, 0.5 d} d
$$

5- S. El-Gamal, E.F. El-Salakawy, and B. Benmokrane [9]

$$
\begin{gathered}
V_{c}=V_{c, A C I 318} \times \alpha(1.2)^{N}=0.33 \alpha(1.2)^{N} \sqrt{f^{\prime} c} b_{o} d \quad \text { Eq. (5) } \\
\alpha=0.5 \sqrt[3]{\rho E}\left(1+\frac{8 d}{b_{o}}\right) \quad \text { Eq. (5a) }
\end{gathered}
$$

Where $\mathrm{N}$ is the continuity factor taken as 0 (for one panel slabs); 1 (for slab continuous along one axis) and 2 (for slabs continuous along their two axes)

\section{6- Ibrahim M. Metwally [10]}

$$
V_{c}=0.368 \alpha(1.2)^{N} \sqrt{f^{\prime} c} b_{o} d \text { (SI units) Eq. (6) }
$$

7- Sadjad Amir Hemzah, Salam Al-Obaidi and Thulfiqar Salim (2019) [11]

$$
V_{c}=\frac{1}{3} \sqrt{f^{\prime} c} b_{o} d m . k \quad \text { Eq. (7) }
$$

Where (m) is a modifying factor, which takes into account the effects of the concrete compressive strength the reinforcement ration $(\rho)$ and the modulus of elasticity as explained in Eq. (7a) below

$$
m=\left(\frac{90}{f^{\prime} c}\right)^{0.33} \cdot(5 \rho)^{0.39} \cdot\left(\frac{E}{E_{s t}}\right)^{0.3} \quad \text { Eq. (7a) }
$$

The (k) factor is also a modifying factor for the column's shape which is taken as 0.77 for circular columns and as 0.55 for square or rectangular columns 
8- Stijn Matthys and Luc Taerwe (2000) [12]

$$
V_{c}=1.36 \frac{\sqrt[3]{\left(100 \rho_{f} f^{\prime} c\left(\mathrm{E}_{f} / \mathrm{E}_{s}\right)\right)}}{\sqrt[4]{d}} b_{o, 1.5 d} \cdot d \quad \text { Eq. (8) }
$$

9- C. E. Ospina, S. D. B. Alexander, and J. J. Roger Cheng [13]

$$
V_{c}=2.77 \sqrt[3]{\left(\rho_{f} f^{\prime} c\right)} \sqrt{\left(\mathrm{E}_{f} / \mathrm{E}_{s}\right)} b_{o, 1.5 d} \cdot d \quad \text { Eq. (9) }
$$

10- Ilker Fatih Kara and Besian Sinani (2017) [14]

$$
V_{c}=0.46 \sqrt[3]{\left(100 \rho_{f} f^{\prime} c\left(\mathrm{E}_{f} / \mathrm{E}_{s}\right)\right)} b_{o, 1.5 d} \cdot d
$$

11- Zaghloul, A., and Razaqpur, A.(2004) [15]

$$
v_{c}=0.07 \lambda \varphi_{c} \sqrt[3]{\left(\rho f^{\prime} c E_{f}\right)}
$$

\section{EXPERIMENTAL PROGRAM}

In the present study, totally 8 square footing with a square column stubs were tested. The size of the tested footings were chosen to be approximately equal to $(1 / 2: 1 / 3)$ of the size of a common footings usually used in medium height buildings.

\subsection{Test specimens}

All the investigated footings had the same depth of $170 \mathrm{~mm}$, constant concrete cover of $35 \mathrm{~mm}$, and a variable footprint of $1050 \mathrm{~mm} \times 1050 \mathrm{~mm}$ and $1250 \mathrm{~mm} \times 1250 \mathrm{~mm}$. For all specimens a square column stubs were prepared at the footing center with a dimensions of $150 * 150 \mathrm{~mm}$ and $150 \mathrm{~mm}$ height with four $12 \mathrm{~mm}$ diameter steel bars as a main reinforcement and three $10 \mathrm{~mm}$ diameter steel rebars stirrups as transverse reinforcement. The test parameters investigated were the shear span to depth ratio $(a / d)$ varied from 3.46 to 4.23 , the reinforcement bars type (FRB and steel bars) and the ratio of reinforcement $(0.5 \%$ and $1.0 \%)$. All tested footings had the same concrete strength $\left(f^{\prime} c\right)$ of $20 \mathrm{MPa}$. To present the soil interaction effect all footings were realistically supported on a sand bed. The tested footings were divided in two series, (GF and SF) Table (1) Fig.(1a,b,c,d,e,f,g,h) gives the full details of the tested footings. 
Table (1) Tested Footings Details

\begin{tabular}{|c|c|c|c|c|c|c|c|c|}
\hline $\begin{array}{c}\text { specimen } \\
\text { Series GF }\end{array}$ & $L(\mathrm{~mm})$ & $B(\mathrm{~mm})$ & $h(\mathrm{~mm})$ & $d(\mathrm{~mm})$ & \multicolumn{3}{|c|}{$a / d$} & \multicolumn{3}{|c|}{ reinforcement } \\
\hline GF3 & 1,050 & 1,050 & 170 & 130 & 3.46 & 9 & 10 & 0.5 \\
\hline GF4 & 1,050 & 1,050 & 170 & 130 & 3.46 & 17 & 10 & 1.0 \\
\hline GF5 & 1,250 & 1,250 & 170 & 130 & 4.23 & 11 & 10 & 0.5 \\
\hline GF6 & 1,250 & 1,250 & 170 & 130 & 4.23 & 21 & 10 & 1.0 \\
\hline Series SF & & & & & & & & \\
\hline SF3 & 1,050 & 1,050 & 170 & 130 & 3.46 & 9 & 10 & 0.5 \\
\hline SF4 & 1,050 & 1,050 & 170 & 130 & 3.46 & 17 & 10 & 1.0 \\
\hline SF5 & 1,250 & 1,250 & 170 & 130 & 4.23 & 11 & 10 & 0.5 \\
\hline SF6 & 1,250 & 1,250 & 170 & 130 & 4.23 & 21 & 10 & 1.0 \\
\hline
\end{tabular}

$\mathrm{L}$ : footing length, B: footing width, h:footing height, d:effective depth $=\mathrm{h}$ - concrete cover - $(\Phi / 2)$, a/d: shear span to depth ratio, n: bars number, $\Phi$ : bar's diameter and $\boldsymbol{p}:$ reinforcement ratio

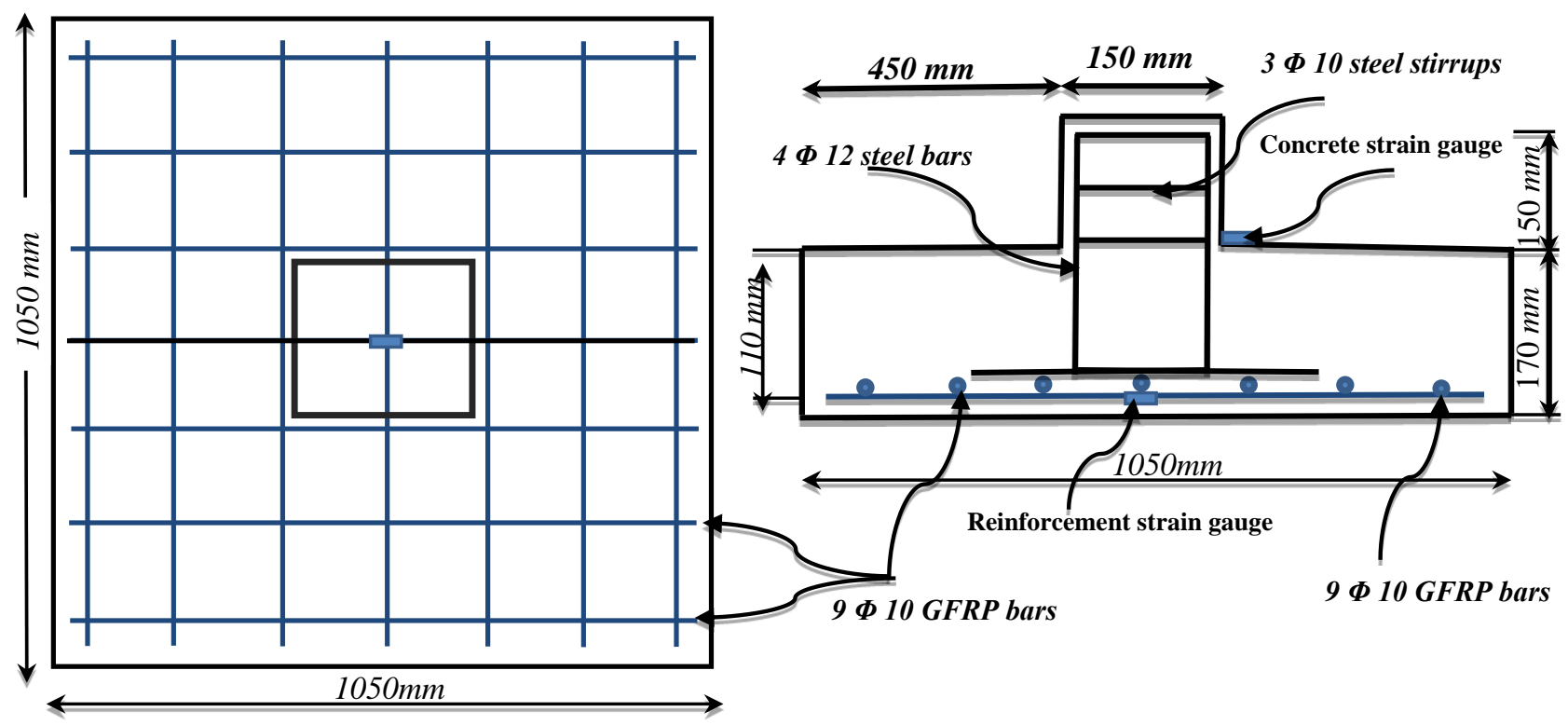

Fig.(1a) footing GF3 details 


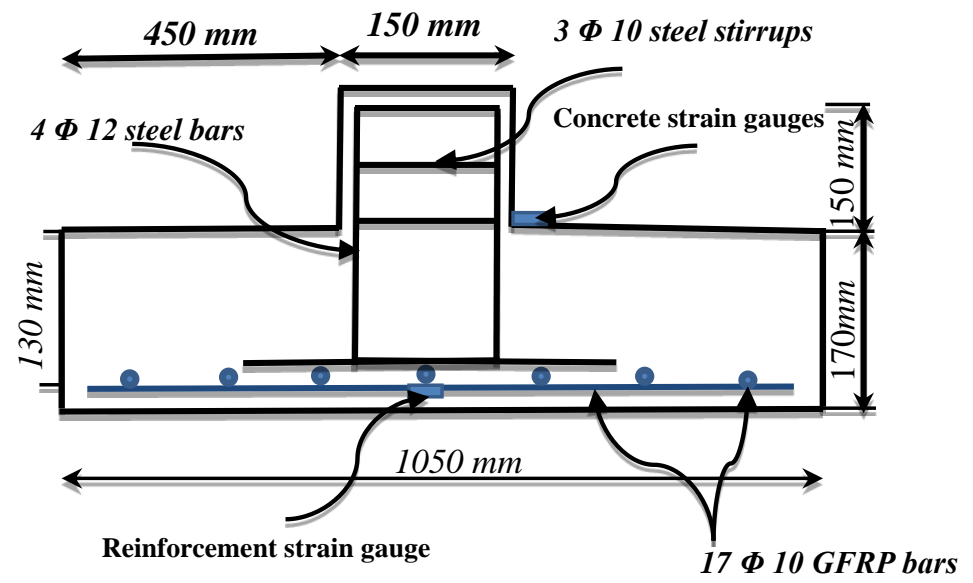

Fig.(1b) footing GF4 details

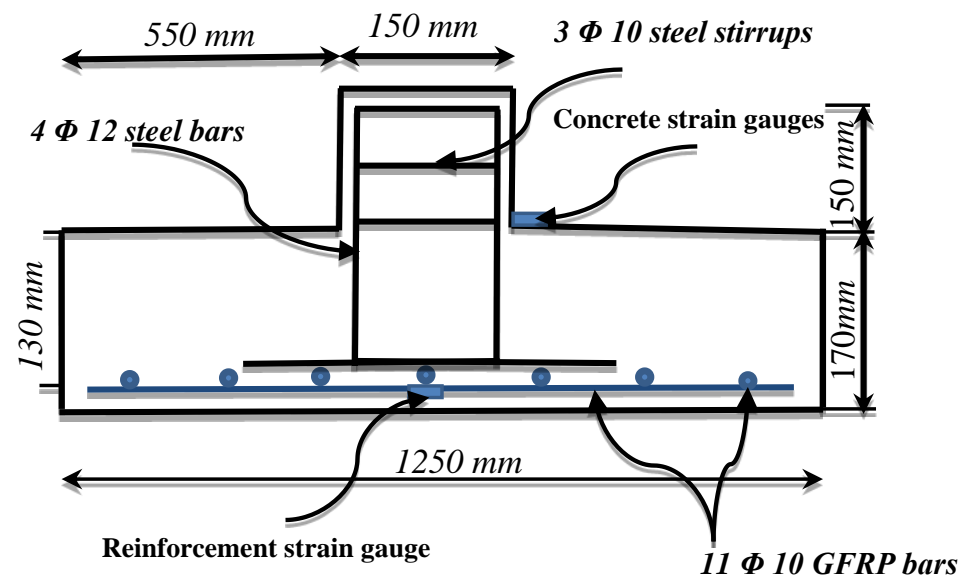

Fig.(1c) footing GF5 details
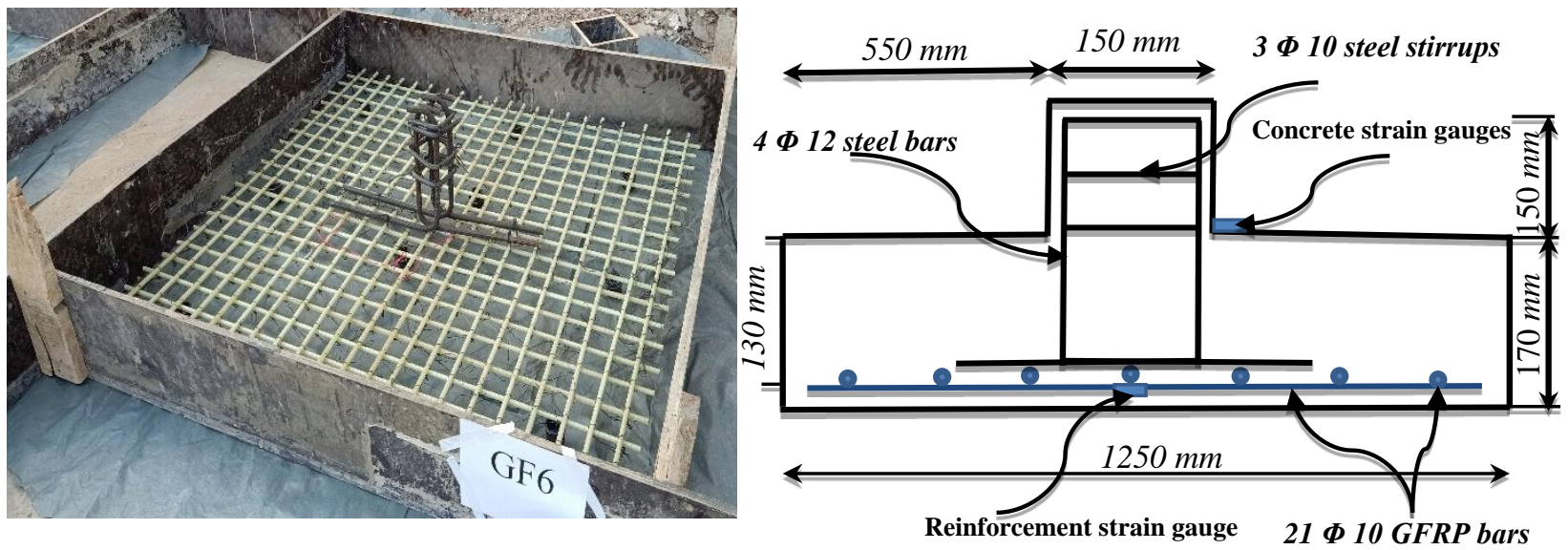

Fig.(1d) footing GF6 details 


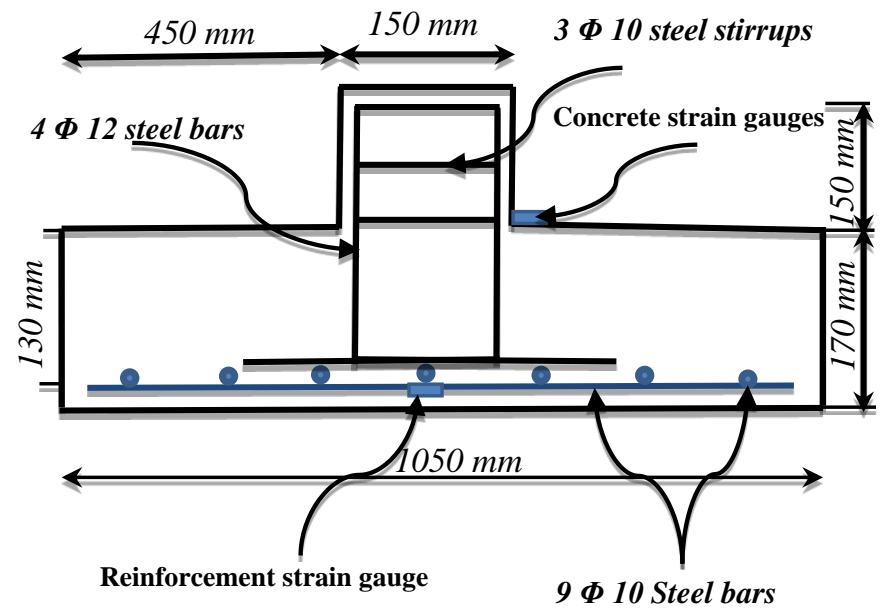

Fig.(1e) footing SF3 details

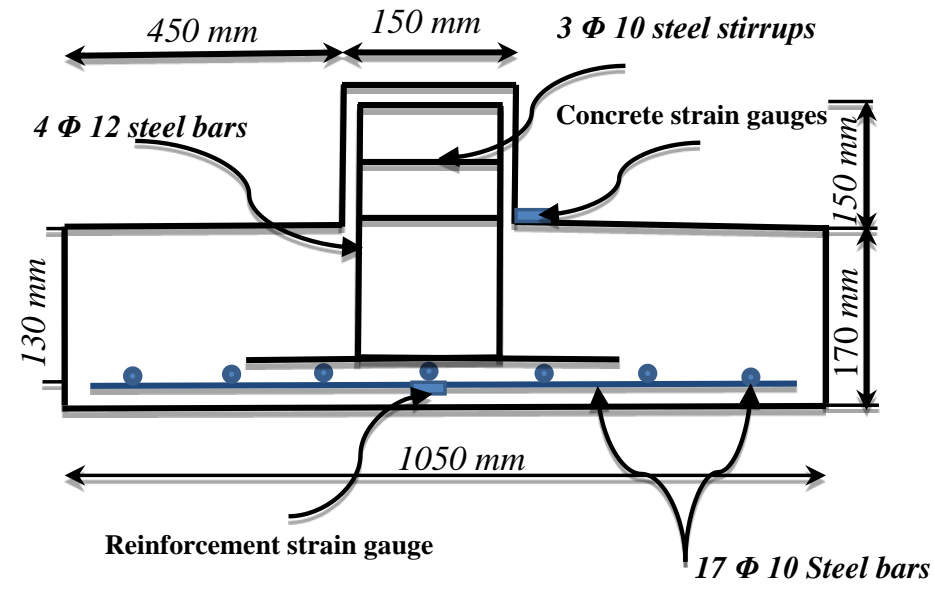

Fig.(1f) footing SF4 details

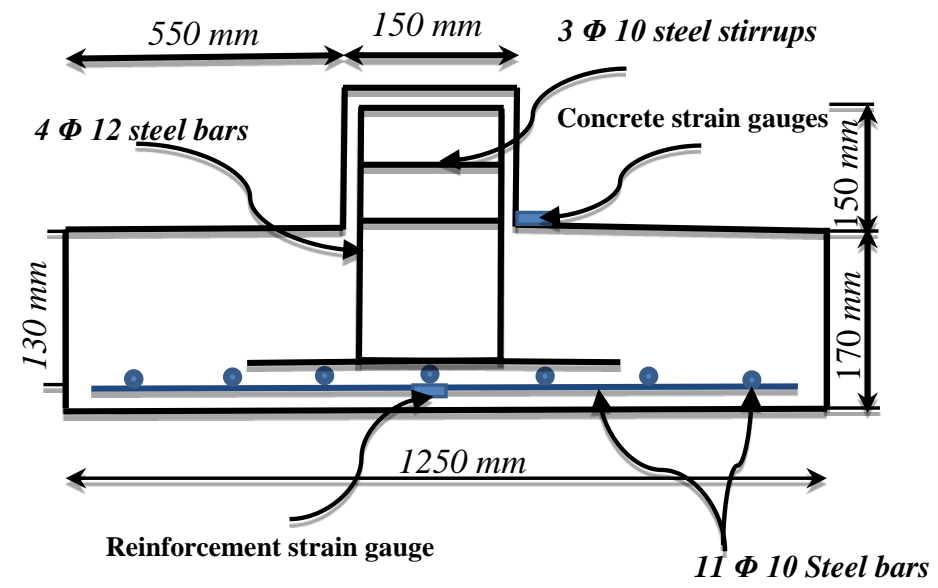

Fig.(1g) footing SF5 details 


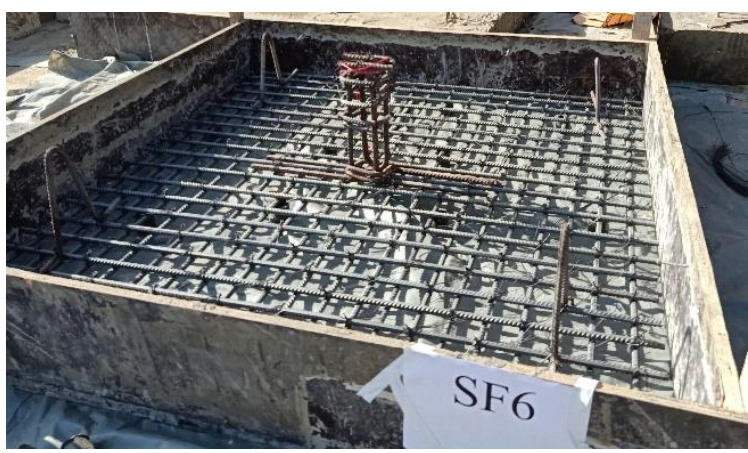

Fig.(1h) footing SF6 details

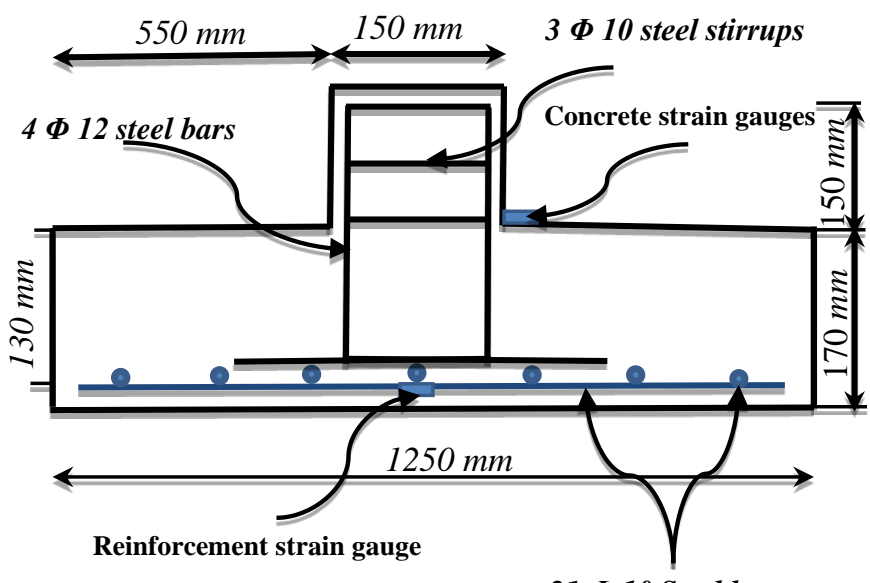

$21 \Phi 10$ Steel bars

\subsection{Material Properties}

\subsubsection{Reinforcement Bars}

\section{a) GFRP Bars}

Ribbed bars of Glass Fiber Reinforced Polymers (GFRP bars) with $10 \mathrm{~mm}$ diameters manufactured by Fiber Reinforcement Industries company. (Fri-Co), with $80 \%$ of glass Fibers content in volume, were used as main reinforcement in the tested concrete specimens (series GF). For obtaining the tensile strength, ultimate strain, and elastic modulus of the bars, five specimens of used GFRP bars were tested following ASTM D7205/D7205M-06 [16] with a total length of $1000 \mathrm{~mm}$. The specimens length chosen to be the sum of free length plus two times the anchor length. The free length equals $400 \mathrm{~mm}$ (40 times the diameter of the FRP bar $\geq 100 \mathrm{~mm}$ ), and the lengths of the anchoring sections equal 300 mm (two steel tubes of $300 \mathrm{~mm}$ length and $4.8 \mathrm{~mm}$ thickness) Fig.2 The test results are shown in Table 2.

\section{Table 2 Test results of the tested used bars}

\begin{tabular}{|c|c|c|c|c|c|}
\hline \multirow{2}{*}{ Properties } & \multicolumn{5}{|c|}{ Sample No. } \\
\cline { 2 - 6 } & 1 & 2 & 3 & 4 & 5 \\
\hline Nominal Diameter $(\mathrm{mm})$ & 10 & 10 & 10 & 10 & 10 \\
\hline Nominal Area $\left(\mathrm{mm}^{2}\right)$ & 78.57 & 78.57 & 78.57 & 78.57 & 78.57 \\
\hline Mass Per Meter Run $(\mathrm{gm} / \mathrm{m})$ & \multicolumn{5}{|c|}{138.0} \\
\hline Ultimate Load $(\mathrm{kN})$ & 85.5 & 77.84 & 80.72 & 83.46 & 78.27 \\
\hline Ultimate Tensile Strength(Mpa) & 1088.2 & 991.09 & 1027.36 & 1062.24 & 996.18 \\
\hline Max. Strain & 0.0253 & 0.0230 & 0.0239 & 0.0247 & 0.0231 \\
\hline
\end{tabular}




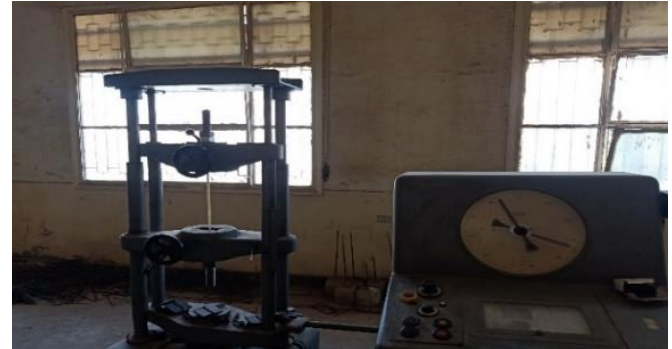

(a)_GFRP tensile Strength method machine

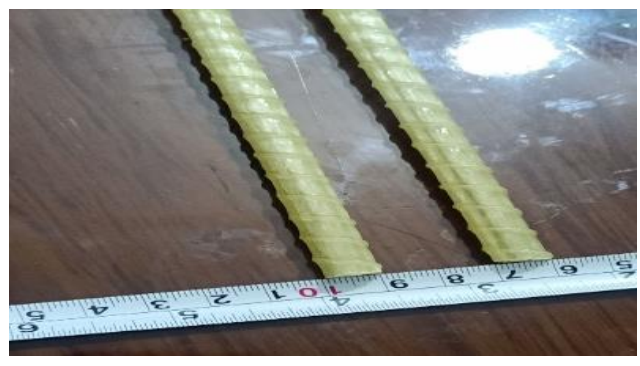

(b) Used GFRP bars with a diameter of $10 \mathrm{~mm}$

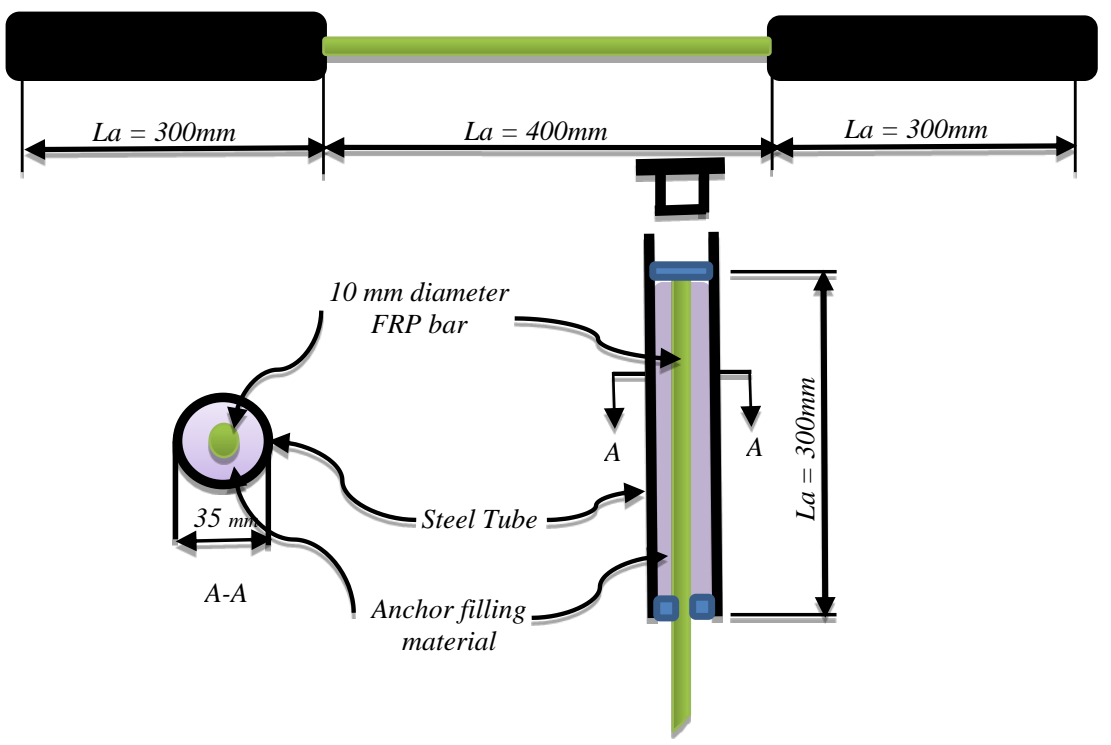

Fig. 2 Tensile properties method sample for used GFRP bars with a diameter of $10 \mathrm{~mm}$

b) Steel Bars

High strength steel ribbed bars manufactured by Egyptian Steel Company grade 400/600, with $10 \mathrm{~mm}$ diameters and with a nominal yield strength of $400 \mathrm{MPa}$ and $200 \mathrm{GPa}$ elasticity modulus, were used as main reinforcement in the tested concrete specimens (series SF) and as a transverse reinforcement for column stubs for all specimens. High strength steel ribbed bars grade 400/600, with 12 mm diameters and with a nominal yield strength of $400 \mathrm{MPa}$ and elasticity modulus $200 \mathrm{GPa}$, were used as a longitudinal reinforcement of columns stubs for all specimens.

\subsubsection{Concrete}

a) Concrete Mix 
Medium strength concrete with a target compressive strength of $30 \mathrm{MPa}$ at 28 days using crushed dolomite aggregate with a maximum nominal size of $20 \mathrm{~mm}$ and ordinary Portland cement CEM I $52.5 \mathrm{~N}$ manufactured by Sinai cement company were used in all footings. Table 3 summarizes the proportions of ingredients used for the concrete mix.

Table 3 concrete mix proportions of ingredients

\begin{tabular}{|c|c|}
\hline Ingredients & Quantity $\left(\mathrm{kg} / \mathrm{m}^{3}\right)$ \\
\hline Ordinary Portland Cement (CEM I A 52.5 N) & $\mathbf{3 6 0}$ \\
\hline Coarse Aggregate & $\mathbf{1 2 6 0}$ \\
\hline fine Aggregate & $\mathbf{6 4 0}$ \\
\hline \multicolumn{2}{|c|}{ w/c $=0.62$} \\
\hline
\end{tabular}

b) Aggregate

The fine aggregates used in this study were natural, clean, and round sand. The sand was washed and dried in an open area before used.

Clean crushed natural Dolomite was used in the mixture as a coarse aggregate with two sizes of (10 and 20) $\mathrm{mm}$. The coarse aggregate was washed using potable water to remove dust or impurities that might exist.

c) Mixing Process, Placing, and Curing

For the mixture used in this study, the cement and sand had first to be dry-mixed for 30 seconds, and then the coarse dry aggregate was added and mixed with the cement and sand for one minute until a uniform color. Water was then added slowly. The mixing process was continued for approximately 4 minutes after water addition. The concrete was poured from the mixer after finishing mixing directly into the formwork. An electrical vibrator was used to remove any air voids. Vibrating the concrete was processed slowly, especially around the strain gauges. From the concrete prepared in the laboratory for all specimens, six standard cubes $150 \mathrm{~mm} \times 150 \mathrm{~mm} \times 150 \mathrm{~mm}$ were prepared. the next day of casting, the cubes were removed and placed inside a curing tank. All six cubes and footings were tested after 43 days of the casting date. Table 4 summarizes the compressive strength of the prepared cubes specimens.

\subsection{Test Setup and Instruments}

For each specimen, three vertical displacements at the center of one face of the column stub and the slab corners were measured using three linear variable differential transformers (LVDT's) gauges. For 
the flexural reinforcement, one electrical strain gauge was attached to the intermediate reinforcing bar with a length of $10 \mathrm{~mm}$ and $119.6 \Omega \pm 0.4 \%$ gage resistance at the center of the bar below the column center for measuring the maximum reinforcement strain for all footing specimens as shown in Fig 3(a). For all footings, one concrete strain gauge with a length of $67 \mathrm{~mm}$ and $119.8 \Omega \pm 0.2 \%$ gage resistance were glued to the concrete surface at the compression side of the footing near the column face to measure the maximum concrete strains as shown in Fig 3 (b).

Table 4 Concrete strength test results

\begin{tabular}{|c|c|c|}
\hline Cube & Load $(\mathrm{KN})$ & $F_{c u}(\mathrm{Mpa})$ \\
\hline $\mathbf{C}_{\mathbf{1}}$ & 715 & 31.8 \\
\hline $\mathbf{C}_{\mathbf{2}}$ & 637 & 28.3 \\
\hline $\mathbf{C}_{\mathbf{3}}$ & 752 & 33.4 \\
\hline $\mathbf{C}_{\mathbf{4}}$ & 766 & 34.0 \\
\hline $\mathbf{C}_{\mathbf{5}}$ & 646 & 28.7 \\
\hline $\mathbf{C}_{\mathbf{6}}$ & 805 & 35.8 \\
\hline Average & 720.2 & 32.0 \\
\hline
\end{tabular}
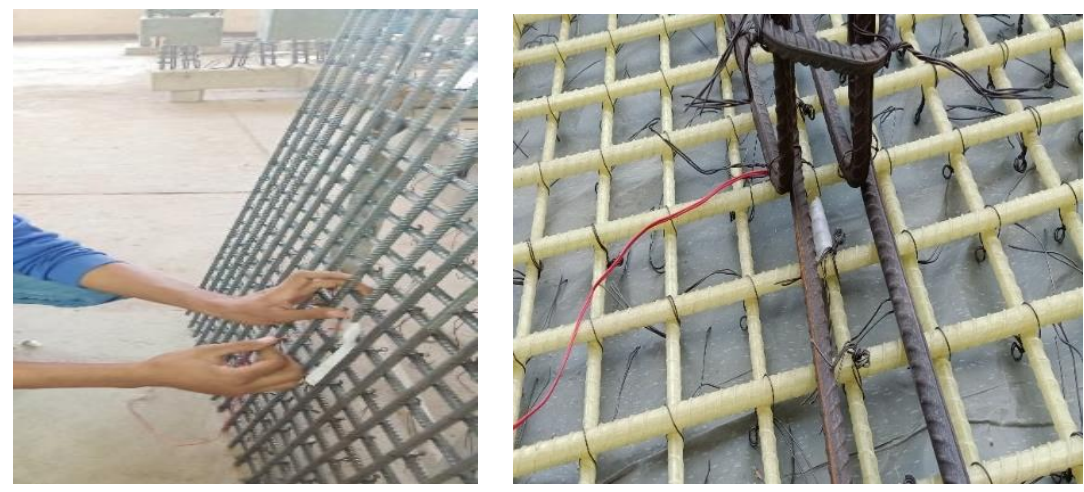

(a) Reinforcement electrical strain gauge location

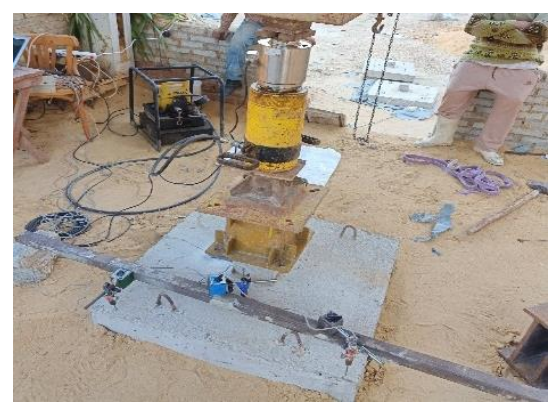

(b) Linear Variable Differential Transformers (LVDT's) Gauges positions

Fig. 3 strain gauges and LVDTs locations 


\subsection{Test Frame}

Fig.4 (a) shows the schematic representation of the test setup frame. The test frame consists of 4 steel columns $(260 \times 260 \mathrm{~mm}$ in cross-section) made from two steel channels for each column connected face to face with steel plates, four edges I-beams connected with the columns by two angels at each end of them. The loading bridge consists of two I-beams connected with steel plates, which were located at the middle of two main edges bridges. The steel loading column was located in the middle of the loading bridge. All four columns were connected with a reinforced concrete ground base. To present the effect of Soil-structure interaction, all footings were realistically supported on a soil bed. The soil box was prepared with dimensions of $3.8 \mathrm{~m} \times 3.8 \mathrm{~m}$ in plan and $2.3 \mathrm{~m}$ in depth. Well-graded sand layers, each $15 \mathrm{~cm}$ in thickness, are placed at the bottom of the frame, and then each of the layers is compacted by a plate compactor to the required modulus of compressibility fig. 4 (b). The compaction level is controlled for each layer by the sand cone test.

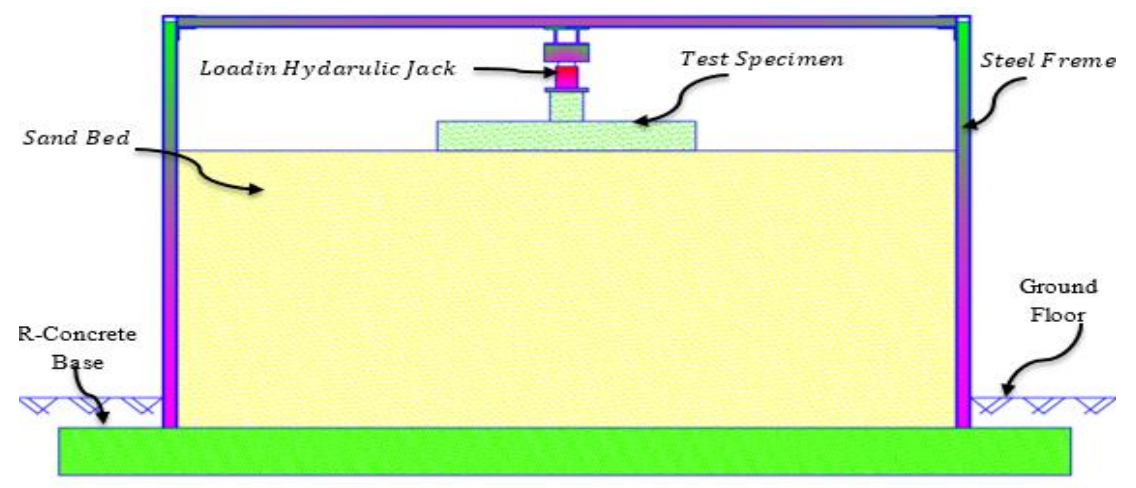

(4-a) Schematic representation of test setup Frame

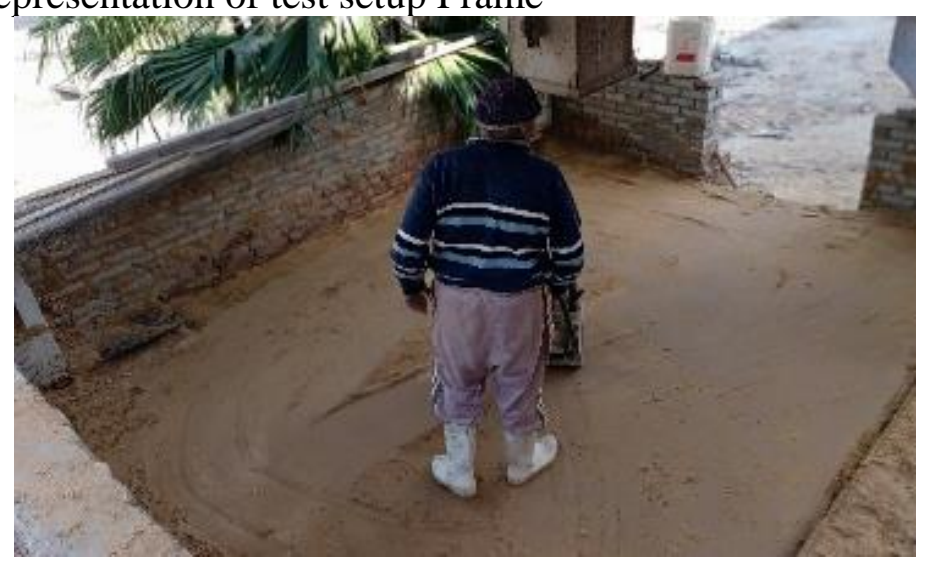

(4-b) sand layers compaction

Fig. 4 Test frame 


\subsection{Testing procedure}

The current footing specimens were tested after 42 days of the casting date. A vertical centric load was applied in increments of approximately $5-10 \mathrm{kN}$ by a hydraulic jack with a maximum capacity of 500 $\mathrm{kN}$ placed between the steel loading column of the steel frame and the column stub. After Pc, service was reached Pcode/2.1 [17] the load was kept constant until total soil settlement took place by observing the vertical displacements with the linear variable differential transformers (LVDT's) gauges. Then the footings were continuously loaded until failure. During the experimental testing, strains in the reinforcement of tested footings, vertical displacements, loading force, and concrete strain at the concrete surface at the compression side of the footing near the column face were measured at every second of the testing time.

\section{EXPEIREMENTAL RESULTS AND DISCUSSION}

\subsection{Test Results}

\subsubsection{Modes of Failure, Failure Load and Crack Pattern}

Regardless of footing longitudinal reinforcement amounts, all footing specimens failed in two-way (punching) shear failure mode with no indications of flexural failure. A brittle failure with a sudden drop of the loaded column had happened and no crushing of the concrete at the footing compression face at the column footing contact area was observed. The compression zone punching capacity was governed by splitting tension of concrete instead of crushing.

Specimen GF4, and GF6 with a reinforcement ratio of $1.0 \%$ showed a little higher punching shear capacity than the analogous specimens GF3, and GF5 with a reinforcement ratio of $0.5 \%$. Where the observed load failure of specimen GF4 and GF6 were equals 302.2 and $252.5 \mathrm{KN}$ respectively and the observed load failure of specimens GF3 and GF5 were equals 296 and $219.6 \mathrm{KN}$ respectively with a reduction of 2.0, $13.0 \%$ respectively.

All of the 4 specimens showed a similar cracking action. It was observed that, flexural cracks happened earlier than the cracks of shear. At first loading stages, the cracks happened at the footings mid-span then at higher loading levels it started to appear near mid-span approximately at the columns face of footings in the footings tension side observed at the four edge sides. Footings GF3 and GF5 with a reinforcement ratio of $0.5 \%$, showed a cracks deeper and wider than that of footings GF4 and GF6 with a reinforcement ratio of $1.0 \%$ at the same loading stages. After failure, the cracks at the footings tension side were studied. It was observed that, the cracks of punching shear dominated the 
circumferential cracks and formed the punching cone. Fig (5.1) shows footings tension side cracks for series GF specimens after failure.

\subsection{Deflection Behaviour}

Fig (5.2) shows the load-deflection relationships for all the tested specimens of series GF. Fig (5.3) shows the relationships of the load and vertical displacements of corners and center of the footings for all the tested specimens of series GF. The vertical displacements were measured be using three LVDTs were located approximately at one of the column corners and tow corners of the four footing corners. Structural deflections of specimens were calculated as the subtraction of the corners average settlement from the displacement of the footing center recorded by LVDTs. Footing specimens GF3, and GF5 with a reinforcement ratio of $0.5 \%$, showed a deflection larger than that of analogous footings GF 4 and GF6 with a reinforcement ratio of $1.0 \%$.

\subsection{Concrete and Reinforcement Strains}

Fig (5.4), (5.5) shows the load-reinforcement strain and the load-concrete strain relationships respectively for all the tested specimens of series GF. It was observed that the strain gauges malfunctioned at $51 \%$ of failure load, at $83 \%$ of failure load and at $78 \%$ of failure load in specimens GF-03, GF-05 and GF-06 respectively after reaching the values of $3243 \mu \mathrm{s}, 4342 \mu \mathrm{s}$ and $4334 \mu \mathrm{s}$ respectively. The cause of strain gauges malfunction may be that the bars strain values exceeded the allowable strain of the strain gauges. In general the strains of the reinforcement bars which measured be using one strain gauge for each footing located at the center of the bar below the column center, varied approximately linear relationship with load increasing after cracking for all footing specimens of series GF as shown in fig.(5.4). In addition, it was observed that at service loads $\mathrm{P}_{\text {code }} / 2.1$ [17], the reinforcement strains of specimens GF4, and GF6 with a reinforcement ratio of $1.0 \%$ were smaller than those of the analogous specimens GF3, and GF5 with a reinforcement ratio of $0.5 \%$. Where the reinforcement strains of specimens GF4, and GF6 at service loads represent a ratio of $56 \%$ and $90 \%$ of the reinforcement strains of specimens GF3, and GF5 respectively at the same load.

\subsubsection{The Effect of Shear Span to Depth Ratio (a/d)}

\subsection{Modes of Failure, Failure Load and Crack Pattern}

The parameter of footing shear span (a: is the distance from the footing edge to footing column face) to footing depth (d: is the distance from footing compression side to the center of bottom reinforcement 
bars), were investigated in two values of 3.46 and 4.23. All footing specimens with all investigated (a/d) ratios failed in tow-way (punching) shear failure mode with no indications of flexural failure.

Specimens GF3 and GF4 with (a/d) ratio of 3.46 showed a higher punching shear capacity than the analogous specimens GF5 and GF6 with (a/d) ratio of 4.23. Where the observed load failure of specimens GF3 and GF4 were equals $296 \mathrm{kN}$, and $302.2 \mathrm{kN}$ respectively and the observed load failure of specimens GF5 and GF6 were equals $219.6 \mathrm{kN}$ and $252.5 \mathrm{kN}$ with a reduction of $25.8 \%$ and $16.5 \%$ from the analogous specimens GF3 and GF4 respectively.

\subsection{Deflection Behaviour}

Footing specimens GF3 and GF4 with a shear span to depth ratio of 3.46 showed a smaller deflection than the analogous specimens GF5 and GF6 with (a/d) ratio of 4.23. Where the observed maximum deflection of specimen GF3 and GF4 were equals $5.76 \mathrm{~mm}$ and $6.02 \mathrm{~mm}$ respectively and the observed maximum deflection of specimen GF5 and GF6 were equals $7.9 \mathrm{~mm}$ and $7.1 \mathrm{~mm}$ respectively.

\subsection{Concrete and Reinforcement Strains}

It was observed that at service loads $\mathrm{P}_{\text {code }} / 2.1$ [17], the reinforcement strains of specimens GF3 and GF4 with a shear span (a) to depth (d) ratio of 3.46, showed a smaller values than that of the analogous specimens GF5 and GF6 with (a/d) ratio of 4.23 .

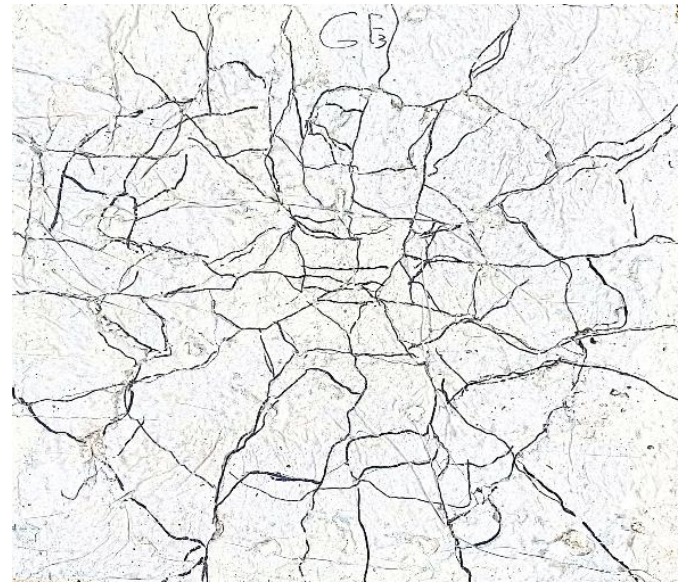

(c) Specimen GF3

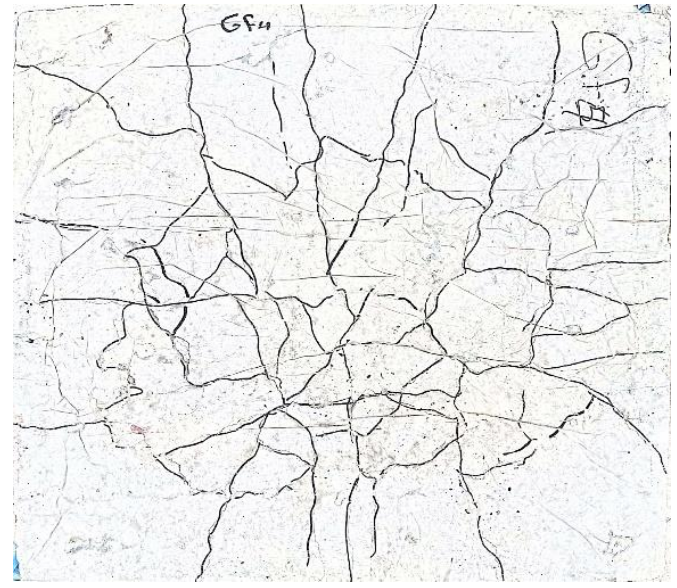

(d) Specimen GF4 


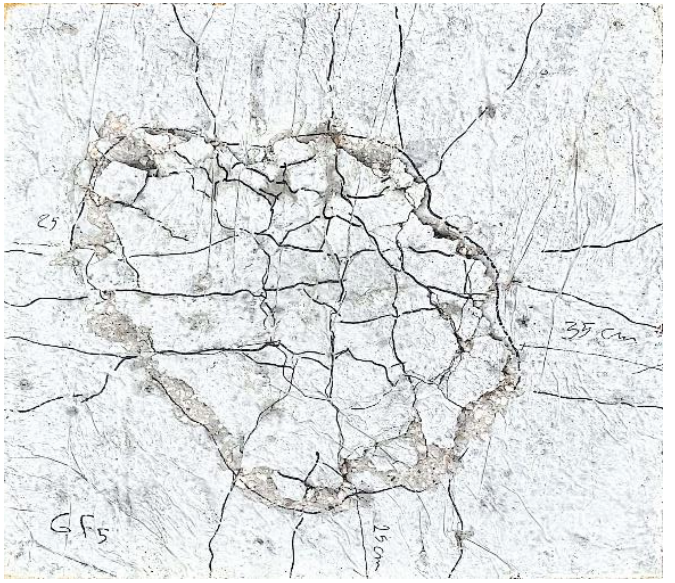

(e) Specimen GF5

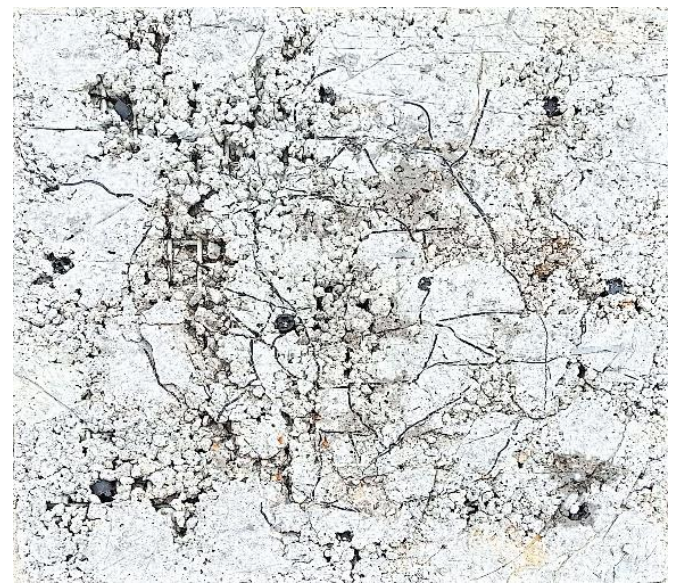

(f) Specimen GF6

Fig (5.1) Footings tension side cracks for series GF specimens after failure
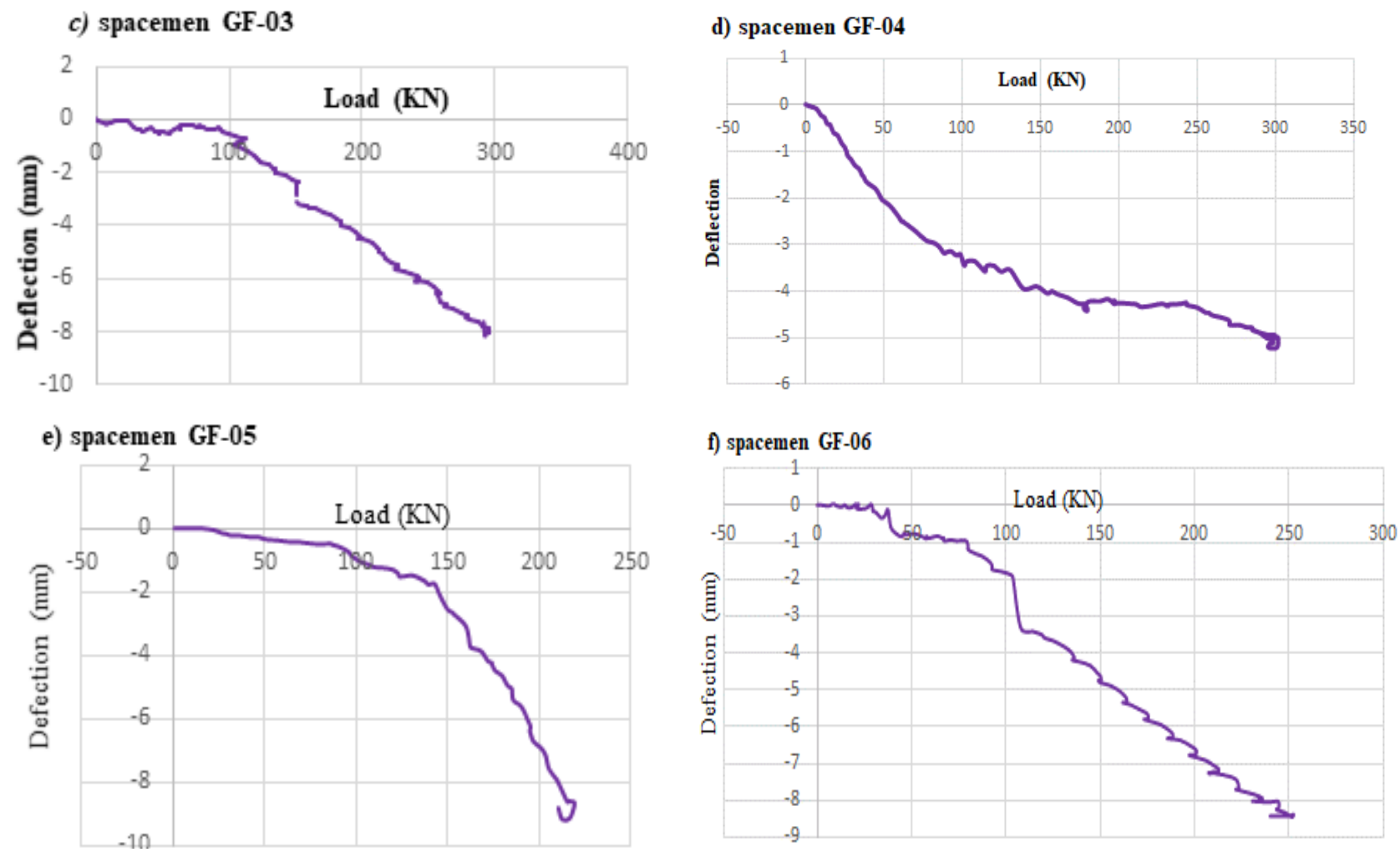

Fig (5.2) the relationship of Load and Deflection of Series GF specimens 

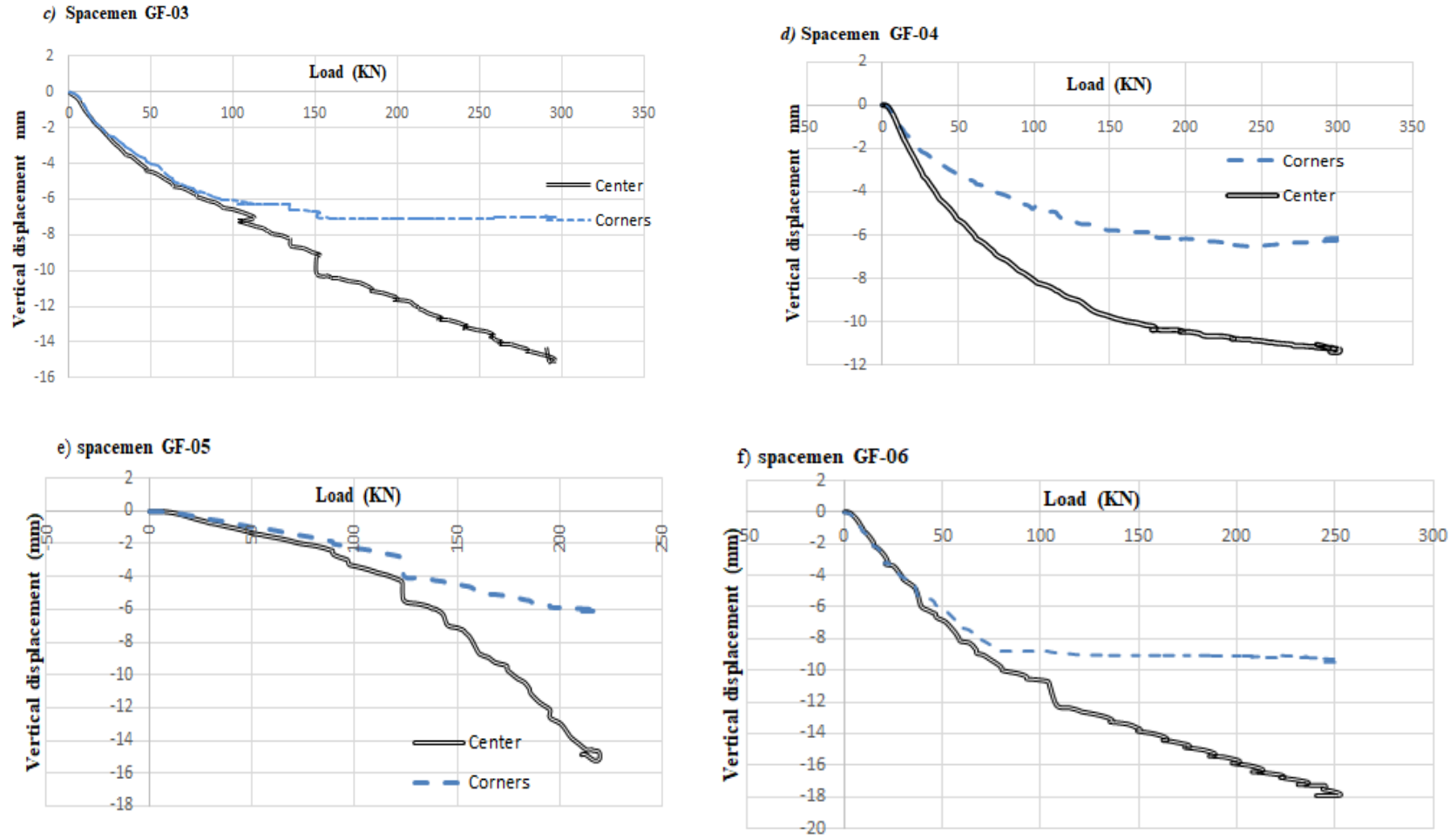

Fig (5.3) the relationship of Load and Vertical Displacement of Series GF
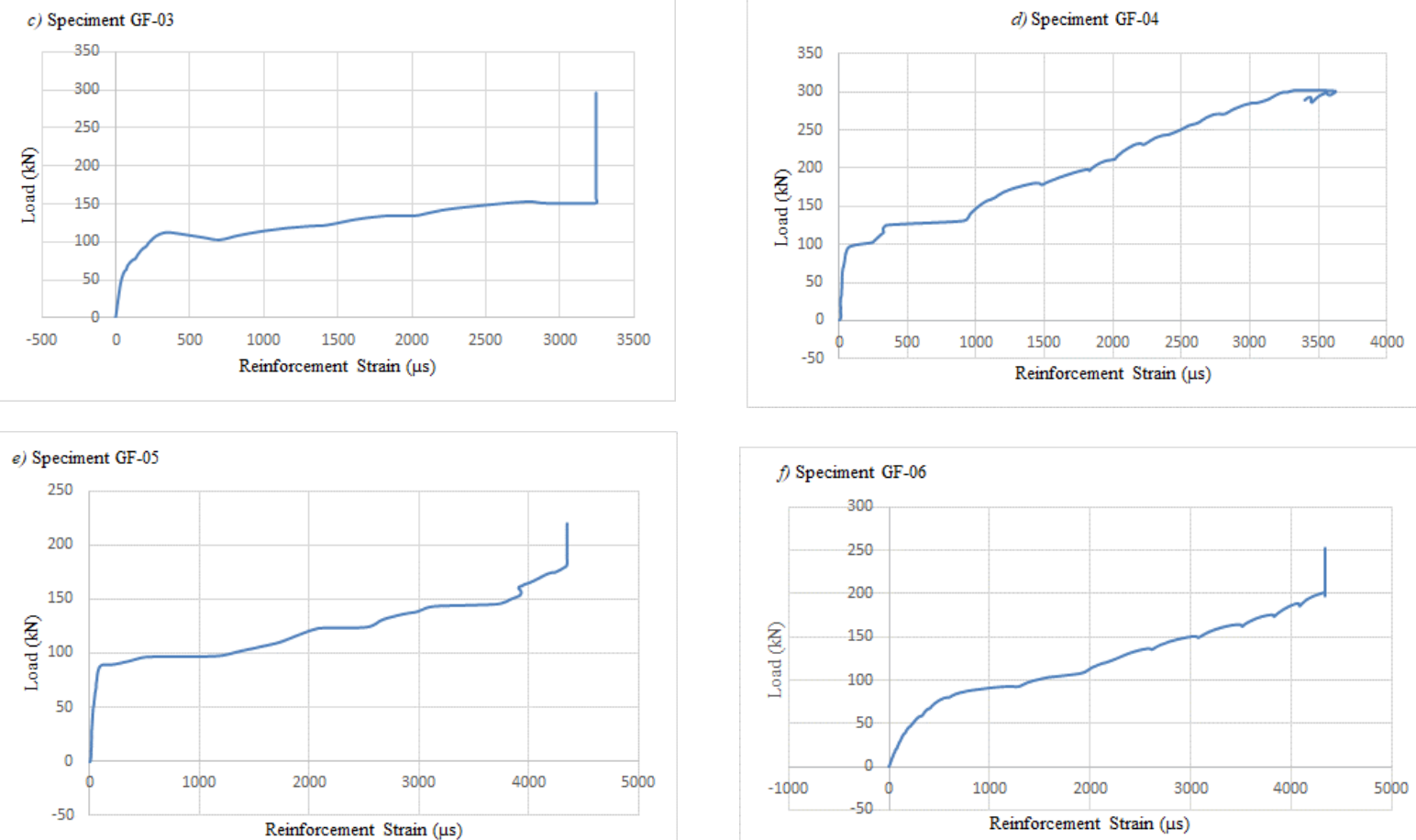

Fig (5.4) the relationship of load and reinforcement strain of series GF specimens 

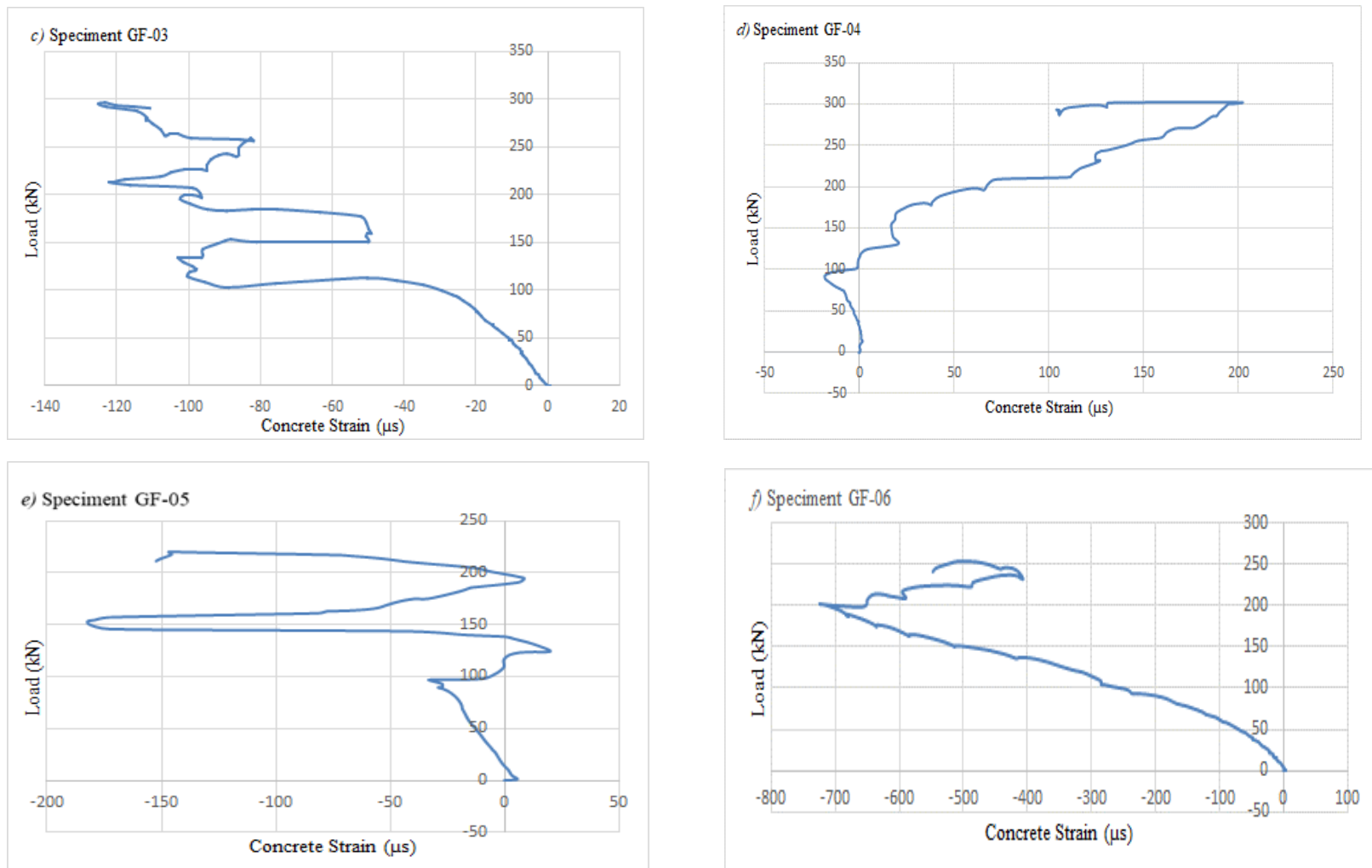

Fig (5.5) the relationship of load and concrete strain of series GF specimens

\subsubsection{Series SF}

\subsubsection{The Effect of Longitudinal Reinforcement Ratio}

\subsection{Modes of Failure, Failure Load and Crack Pattern}

All footing specimens in series SF also failed in tow-way (punching) shear failure mode with no indications of flexural failure. A brittle failure with a sudden drop of the loaded column had happened and no crushing of the concrete at the footing compression face at the column footing contact area was observed. The compression zone punching capacity was governed by splitting tension of concrete instead of crushing.

Specimen SF4, and SF6 with a reinforcement ratio of $1.0 \%$ showed a higher punching shear capacity than the analogous specimens SF3, and SF5 with a reinforcement ratio of $0.5 \%$. Where the observed load failure of specimen SF4 and SF6 were equal to 432.6 and $381.37 \mathrm{KN}$ respectively and the observed load failure of specimens GF3 and GF5 were equal to 353.42 and $278.75 \mathrm{KN}$ respectively with a reduction of 18.30, $26.91 \%$ respectively.

Footings SF3, and SF5 with a reinforcement ratio of $0.5 \%$, showed a cracks deeper and wider than that of footings SF4 and SF6 with a reinforcement ratio of $1.0 \%$ at the same loading stages. After 
failure the cracks at the top of footing tension side were studied. It was observed that, the cracks of punching shear dominated the circumferential cracks and formed the cone of punching. Fig (5.6) shows the circumferential cracks of some footings specimens after failure.

\subsection{Deflection Behaviour}

Fig (5.7) shows the relationships of the load and deflection for all the tested specimens of series SF. Fig (5.8) shows the relationships of the load and vertical displacements of corners and center of the footings for all the tested specimens of series SF. Footing specimens SF3, and SF5 with a reinforcement ratio of $0.5 \%$, showed a deflection larger than that of analogous footings GF4 and GF6 with a reinforcement ratio of $1.0 \%$. Structural deflections of specimens were calculated as the subtraction of the corners average settlement from the displacement of the footing center recorded by LVDTs.

\subsection{Concrete and Reinforcement Strains}

Fig (5.9), (5.10) shows the load-reinforcement strain and the load-concrete strain relationships respectively for all the tested specimens of series SF. In general the strains of the reinforcement bars which measured be using one strain gauge for each footing located at the center of the bar below the column center, varied approximately linear relationship with load increasing after cracking for all footing specimens of series SF. And it was observed that at service loads $\mathrm{P}_{\text {coded }} / 2.1$ [17], the reinforcement strains of specimens SF4, and SF6 with a reinforcement ratio of $1.0 \%$ were smaller than of those of the analogous specimens SF3, and SF5 with a reinforcement ratio of $0.5 \%$.

\subsubsection{The Effect of the Ratio of $(\mathrm{a} / \mathrm{d})$}

\subsection{Modes of Failure, Failure Load and Crack Pattern}

Specimen SF3 and SF4 showed a higher punching shear capacity than the analogous specimens SF5 and SF6 with (a/d) ratio of 4.23. Where the observed load failure of specimen SF3 and SF4 were equal to $353.42 \mathrm{kN}$, and $432.6 \mathrm{kN}$ respectively and the observed load failure of specimens SF5 and SF6 were equal to $278.75 \mathrm{kN}$ and $381.37 \mathrm{kN}$ with a reduction of $21.13 \%$ and $11.84 \%$ from the analogous specimens SF3 and SF4 respectively.

\subsection{Deflection Behaviour}

Footing specimens SF3 and SF4 with a shear span (a) to depth (d) ratio of 3.46, showed a deflection smaller than that of analogous footings SF5 and SF6 with a shear span (a) to depth (d) ratio of 4.23. 
Where the observed maximum deflection of specimen SF3 and SF4 were equals $4.83 \mathrm{~mm}$ and $4.2 \mathrm{~mm}$ respectively and the observed maximum deflection of specimen GF5 and GF6 were equals $6.3 \mathrm{~mm}$ and $5.2 \mathrm{~mm}$ respectively.

\subsection{Concrete and Reinforcement Strains}

It was observed that at service loads ( $\mathrm{P}_{\text {code }} / 2.1$ [17]), the reinforcement strains of specimens SF3 and SF4 with (a/d) ratio of 3.46 showed a smaller values than that of the analogous specimens SF5 and SF6 with $(\mathrm{a} / \mathrm{d})$ ratio of 4.23 .

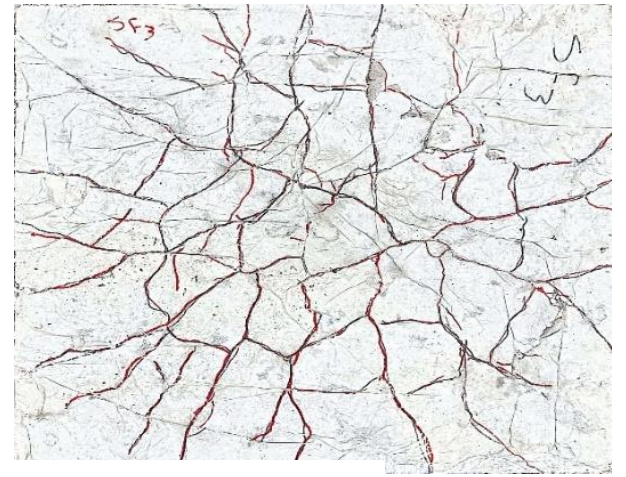

(c) Specimen SF3

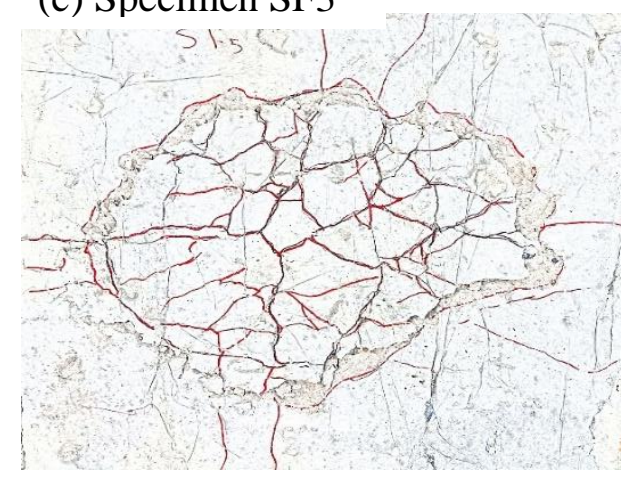

(e) Specimen SF5

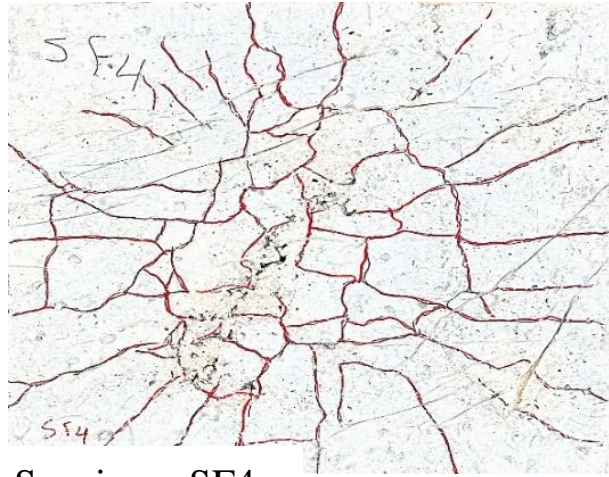

(d) Specimen SF4

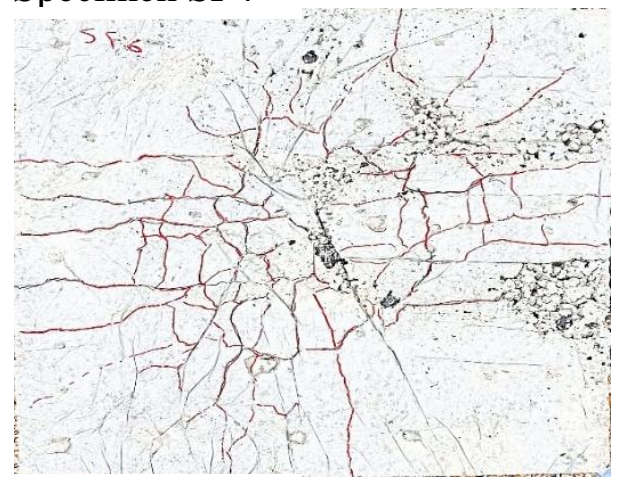

(f) Specimen SF6

Fig (5.6) Footings tension side cracks for series SF specimens after failure 

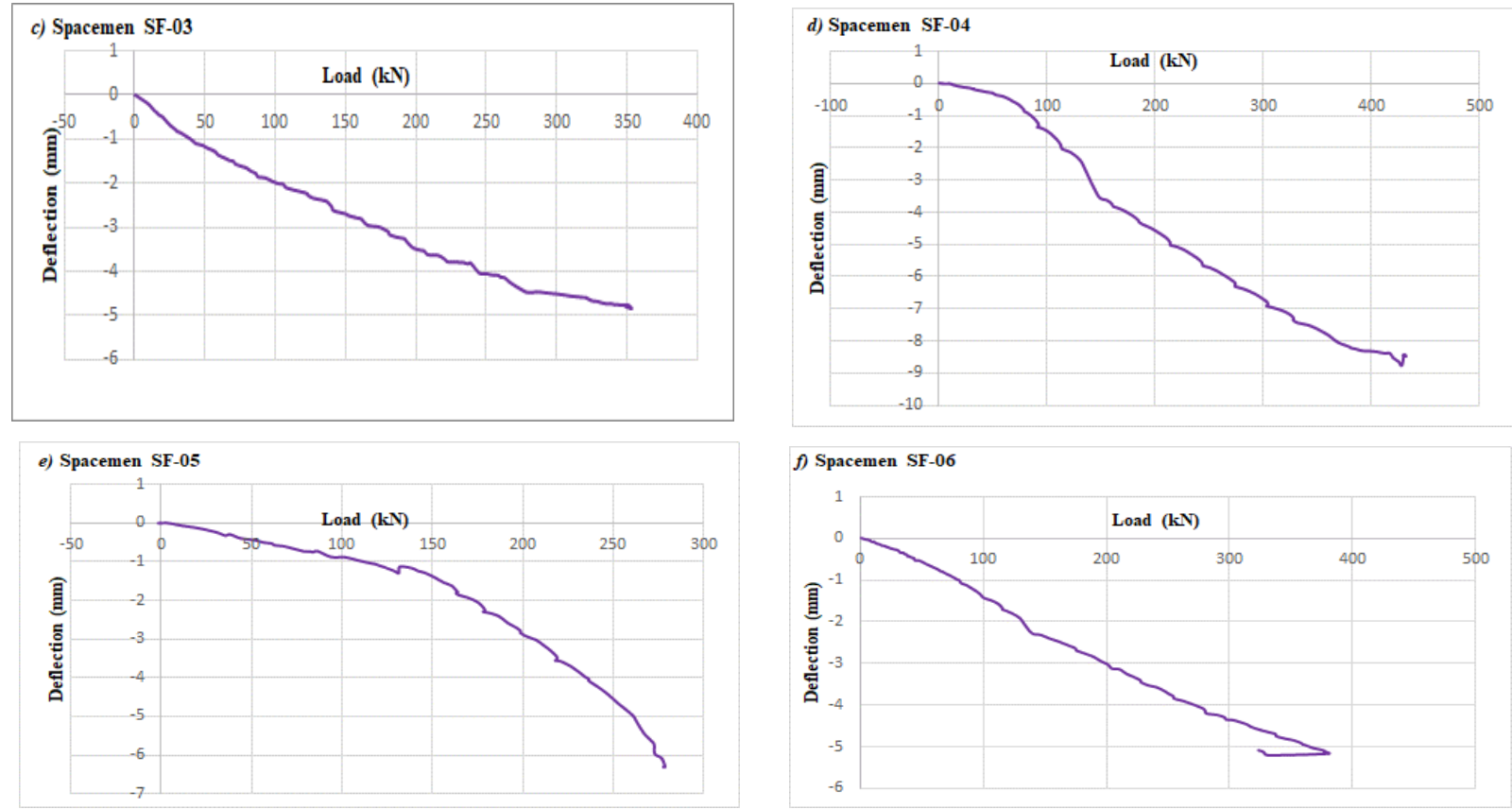

Fig (5.7) the relationship of load and deflection of series SF specimens
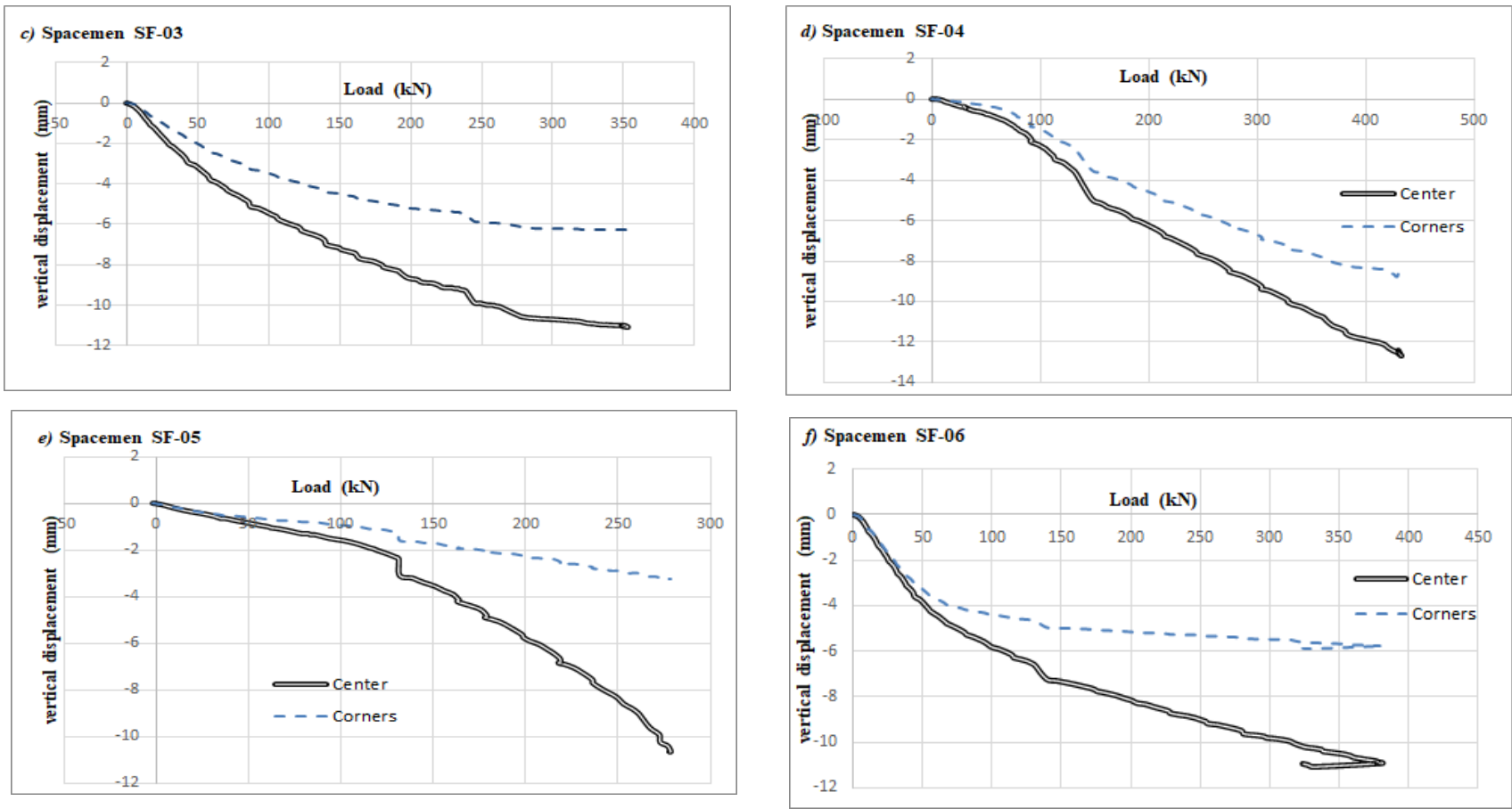

Fig (5.8) the relationship of load and vertical displacement of series SF specimens 

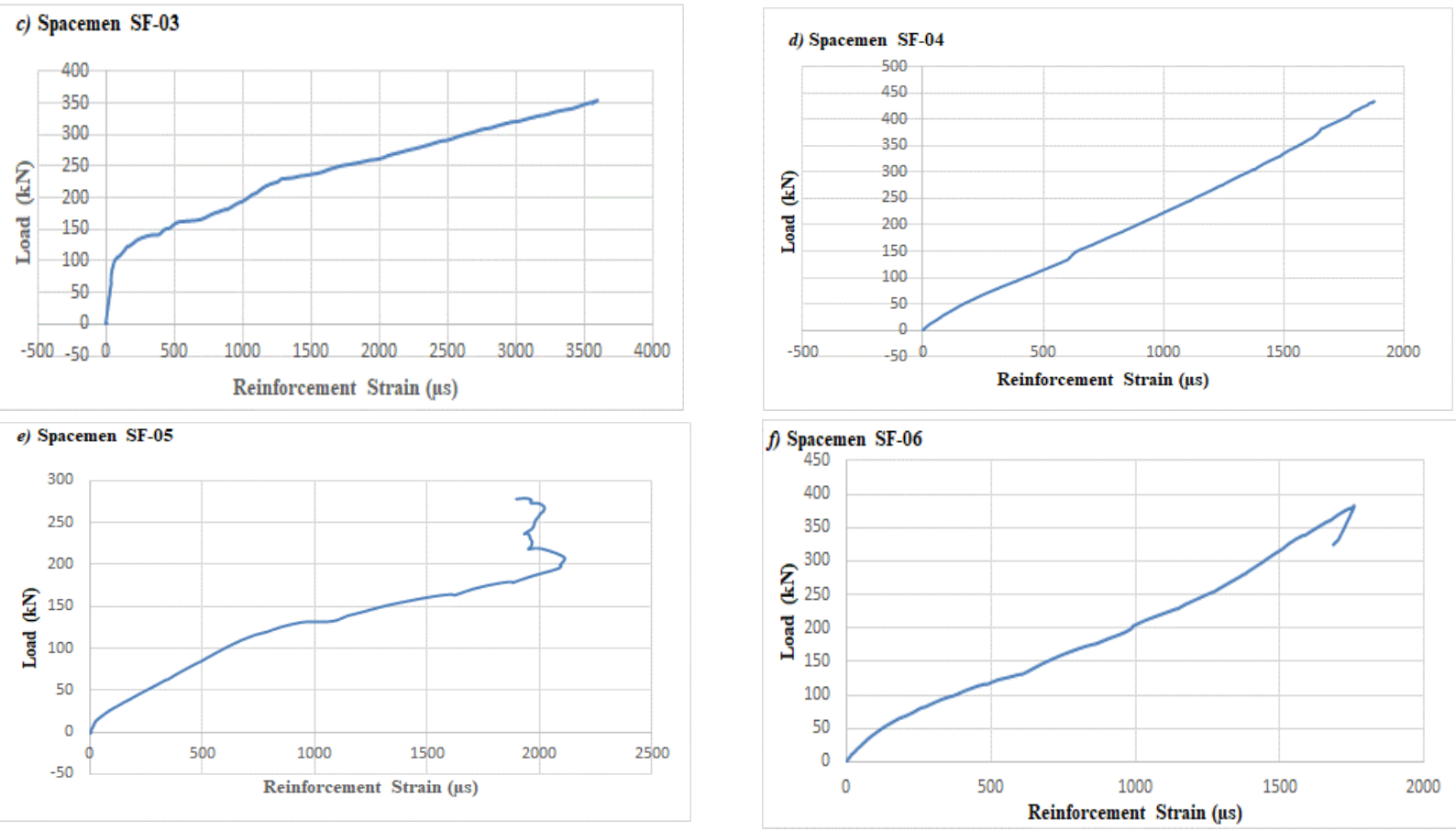

Fig (5.9) the relationship of load and reinforcement strain of series SF specimens
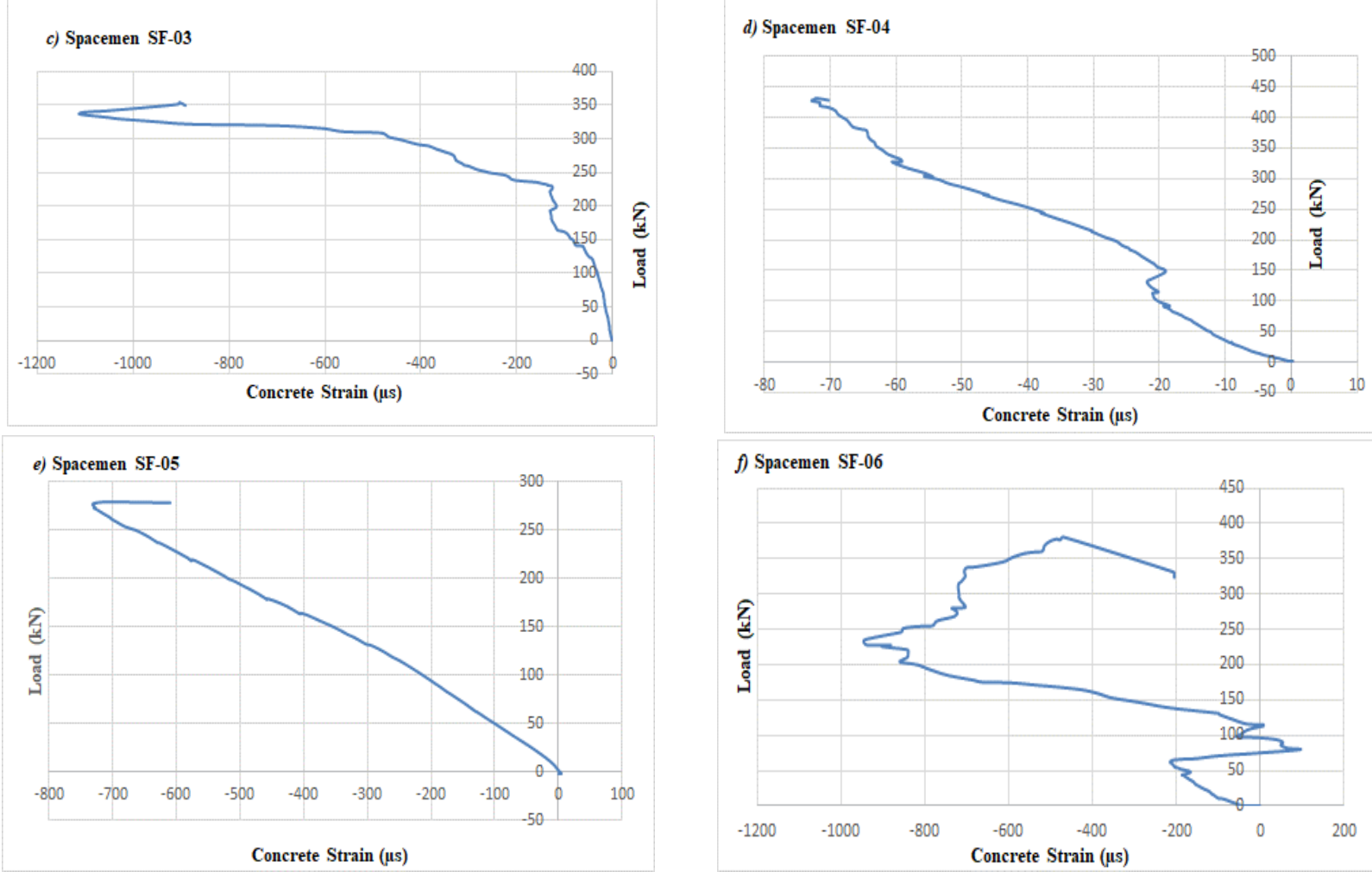

Fig (5.10) the relationship of load and concrete strain of series SF specimens 


\subsection{Results Discussions}

\subsubsection{Longitudinal Reinforcement Ratio Effect}

Dowel action is one of the ways of shear transmission. If the reinforcement bars cross a crack, the shear displacements through the crack will be resisted partially by the bar dowel force. Dowel forces lead to tension stresses in the surrounding concrete with the wedging effect of the bar deformities, causing splitting cracks through the reinforcement (Baumann, T-1968) and (Gergely, P-1969). This declines the concrete stiffness around the bars and the dowel force. Increasing the reinforcement ratio reduce the footing deflection, and reduce the depth of the crack and wide and gives a good aggregate interlocking bond and enhancing the ultimate footing shear capacity.

\subsubsection{The Effect of (a/d) Ratio}

Increasing $(\mathrm{a} / \mathrm{d})$ ratio increases the flexural stress, which create a deeper and wider cracks and leads to the reduction of the aggregate interlocking bond and decrease the overall shear capacity of the footing.

\subsubsection{The Effect of Flexural Reinforcement Type (Steel or GFRP)}

As shown in Fig (5.4) and Fig (5.9) footing specimens reinforced with steel bars in series (SF) show a smaller reinforcement strain than those reinforced with GFRP bars series (GF) because of the relatively smaller modulus of GFRP composite material elasticity. That cause created deeper and wider cracks in footings reinforced with GFRP bars than those of steel-reinforced footings. Deeper cracks reduce the shear strength from the uncracked concrete because of the lower depth of concrete in compression. Wider cracks, in turn, will decline the aggregate interlock contributions and residual tensile strength. "Due to the small transverse strength of FRP bars and wider cracks, dowel action's contribution can be very small compared with that of steel. Finally, FRP R.C footings' overall shear capacity is smaller than that of concrete elements reinforced with steel reinforcement bars" [18].

\subsection{Comparison Between the Failure Ultimate Loads and the Predicted Ultimate Loads}

Table (5) provides experimental and predicted punching shear load values and table (6) summarizes the experimental-to-predicted punching shear load values for all the tested specimens of series GF using the equations shown above ACI440.1R-15 [5], CSA S806-12 design provisions [6], JSCE design recommendations [7], A. W. El-Ghandour, K. Pilakoutas, and P. Waldron [8], S. El-Gamal, E.F. ElSalakawy, and B. Benmokrane [9], Ibrahim M. Metwally [10], Sadjad Amir Hemzah, Salam Al-Obaidi 
and Thulfiqar Salim [11], Stijn Matthys and Luc Taerwe [12], C. E. Ospina, S. D. B. Alexander, and J. J. Roger Cheng [13], Ilker Fatih Kara and Besian Sinani [14], Zaghloul, A., and Razaqpur, A [15]. No factor of safety is considered in all the used equations. All the equations showed a good predictions, except the ACI 440.1R-06 equation which gave a conservative predictions with an average $\mathrm{P}_{c, \text { exp }} /$ $\mathrm{P}_{\mathrm{c}, \text { pred }}$ of $2.83 \pm 0.57$ with a Co. Var. $20.1 \%$.

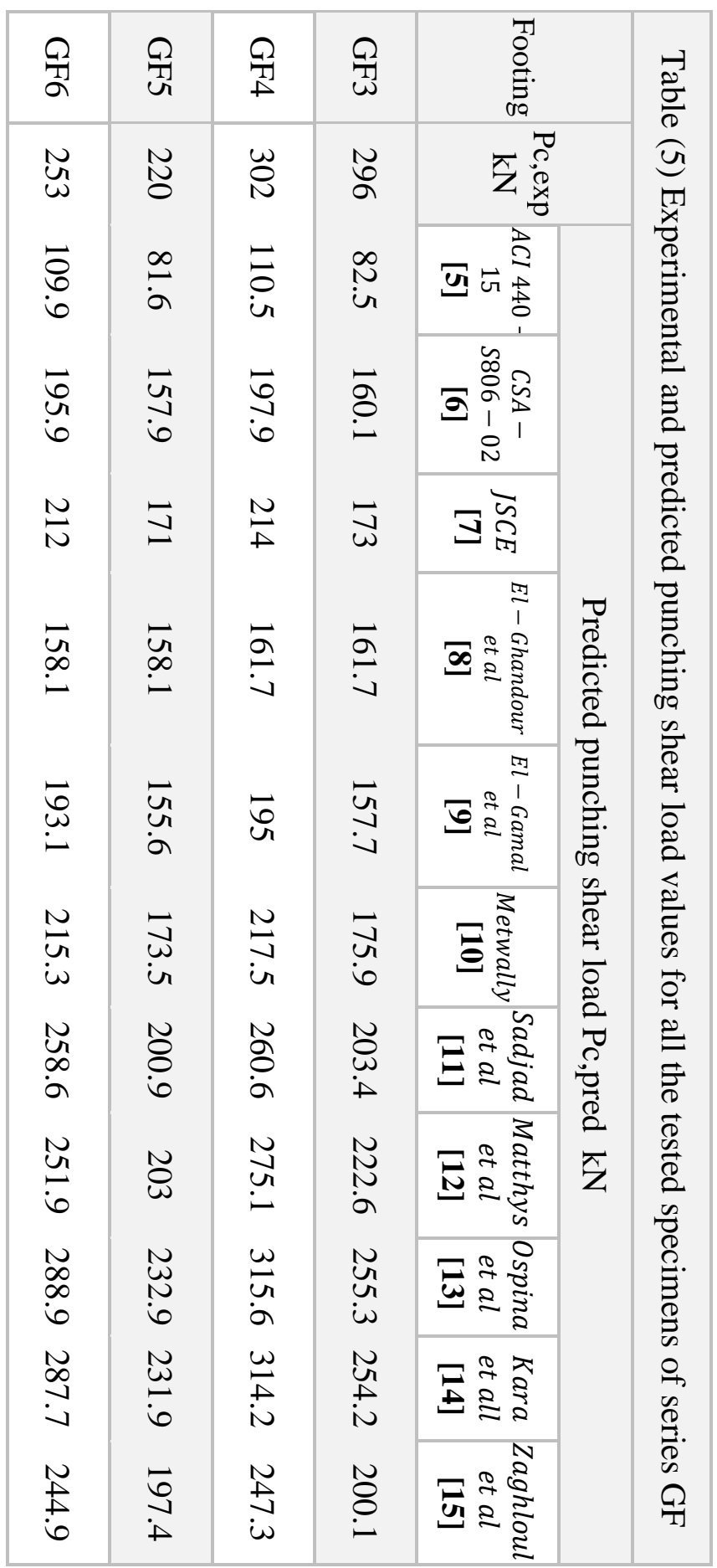




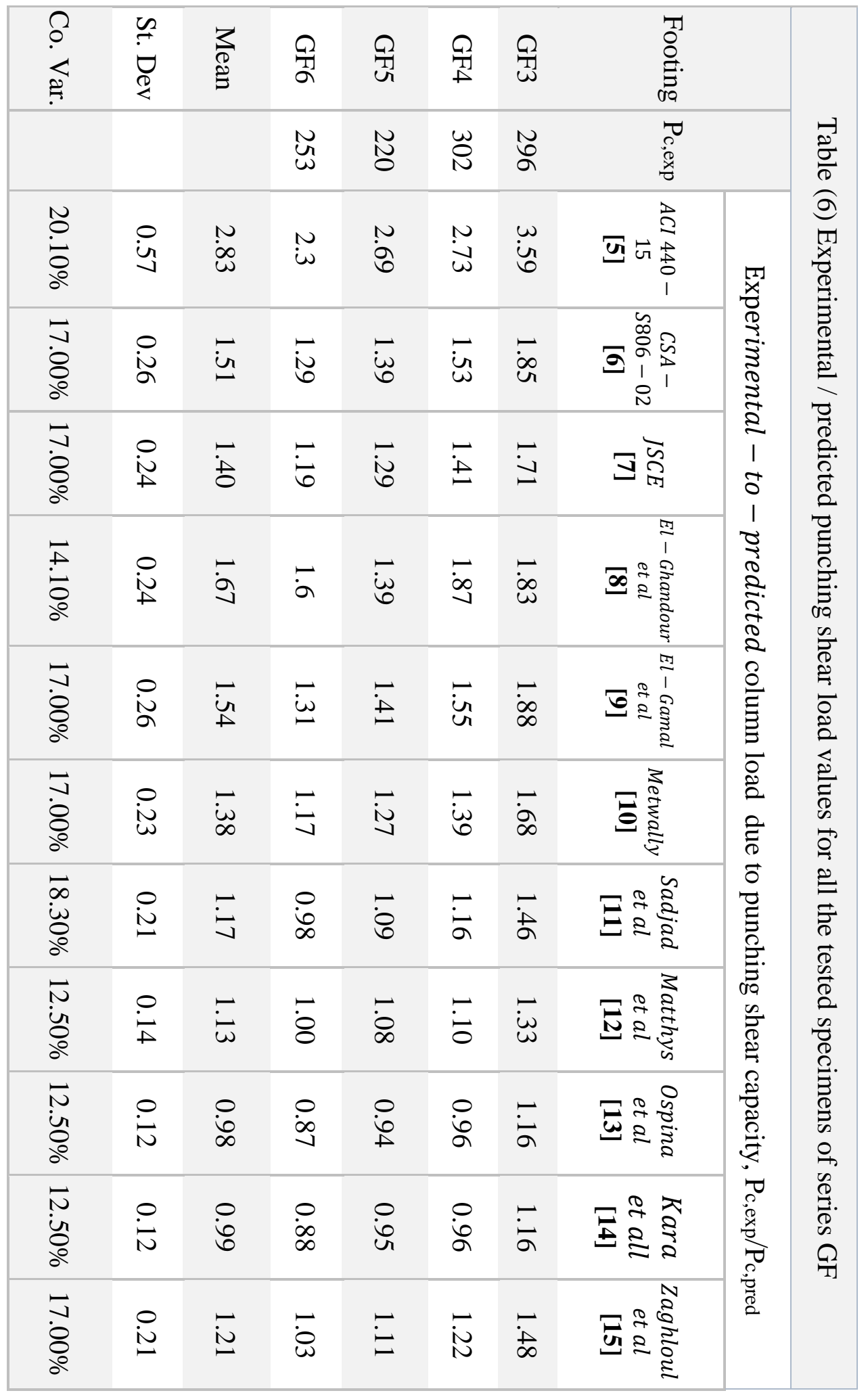




\subsection{Conclusions}

The experimental program of this thesis presents test results for a total of 8 reinforced concrete isolated footings reinforced with GFRP and steel bars to investigate the behavior of isolated footings reinforced with GFRP bars and to compare the results with those reinforced with steel bars. Based on the obtained results from the experimental tests the following conclusion can be presented:

(1) All the tested specimens failed in two-way (punching) shear failure mode with no flexural failure indications. A brittle failure with a sudden drop of the loaded area had happened, and no crushing of the concrete at the footing compression face at the column footing contact area was observed. The compression zone punching capacity was governed by splitting tension of concrete instead of crushing.

(2) The GFRP R.C footings showed wider cracks and larger structural deflection than those similar specimens reinforced with conventional steel bars.

(3) The ultimate capacities of punching shear for GFRP reinforced concrete footing specimens with a longitudinal reinforcement ratio of $0.5 \%$ were smaller than the ultimate capacities of punching shear for footing specimens reinforced with steel bars with a reduction $16.25 \%$ for specimens with $(\mathrm{a} / \mathrm{d})$ ratio of 3.46 and $21.22 \%$ for specimens with $(\mathrm{a} / \mathrm{d})$ ratio of 4.23 .

(4) The ultimate capacities of punching shear for GFRP reinforced footing specimens with a longitudinal reinforcement ratio of $1.0 \%$ were smaller than the ultimate capacities of punching shear for footing specimens reinforced with steel bars with a reduction of $30.14 \%$ for specimens with $(\mathrm{a} / \mathrm{d})$ ratio of 3.46 and $33.79 \%$ for specimens with $(\mathrm{a} / \mathrm{d})$ ratio of 4.23 .

(5) With increasing the reinforcement ratio from $0.5 \%$ in footing specimens with $(\mathrm{a} / \mathrm{d})$ ratio of 3.64 , to $1.0 \%$ the punching shear capacity increased by $2.05 \%$ for GFRP RC footings and $18.30 \%$ for steel RC footing.

(6) With increasing the reinforcement ratio from $0.5 \%$ in footing specimens with $(\mathrm{a} / \mathrm{d})$ ratio of 4.23 , to $1.0 \%$ the punching shear capacity increased by $13.03 \%$ for GFRP RC footings and $26.91 \%$ for steel RC footing. 


\section{References}

[1] Mohammed G. O. M. El-Gendy 2014. "Punching Shear Behaviour of Slab-Column Edge Connections Reinforced with Fibre-Reinforced Polymer (FRP) Composite Bars." Master Thesis, the University of Manitoba.

[2] M.P. Kivi, H. Araghi, A.V. Oskouei, Investigation on GFRP Bar Performance in High Strength Concrete Footing, (2012).

[3] A.V. Oskouei, M.P. Kivi, H. Araghi, M. Bazli, Experimental study of the punching behavior of GFRP reinforced lightweight concrete footing, Materials and Structures 50(6) (2017) 1-14.

[4] Yuguang Yang (2014). "Shear behaviour of reinforced concrete members without shear reinforcement: A new look at an old problem." Doctoral thesis, Delft University of Technology.

[5] ACI Committee 440 (2015),"Guide for the Design and Construction of Structural Concrete Reinforced With Fiber-Reinforced Polymer (FRP) Bars,' ACI 440.1R-15, American Concrete Institute, Farmington Hills, MI.

[6] CAN/CSA S806-12, Canadian Standards Association. "Design and Construction of Building Structures with Fibre-Reinforced Polymers." March 2012.

[7] Japan Society of Civil Engineers (JSCE-1997). "Recommendation for design and construction of concrete structures using continuous fiber reinforcing materials." Tokyo. [8] El-Ghandour, A.W., Pilakoutas, K., Waldron, P. (2003). "Punching shear behavior of fiber reinforced polymers reinforced concrete flat slabs: experimental study." Journal of Composites for Construction, 7 (3), pp. 258-265 http://dx.doi.org/10.1061/(ASCE)10900268(2003)7:3(258).

[9] S. El-Gamal, E.F. El-Salakawy, and B. Benmokrane (2005) . "A New Punching Shear Equationfor Two-Way Concrete Slabs Reinforced with FRP Bars." ACI Special publication. Volume SP-230-50. 877-894.

[10] Ibrahim M. Metwally (2013). "Prediction of punching shear capacities of two-way concrete slabs reinforced with FRP bars." (C) 2013 Housing and Building National

Research Center. Production and hosting by Elsevier B.V. http://dx.doi.org/10.1016/j.hbrcj.2013.05.009.

[11] Sadjad A. Hemzah, Salam Al-Obaidi and Thulfiqar Salim (2019). "Punching Shear Model for Normal and High-Strength Concrete Slabs Reinforced with CFRP or Steel Bars.” (C) 2019 JUST, Jordan Journal of Civil Engineering, Volume 13, No. 2, 2019.

[12] Stijn Matthys and Luc Taerwe (2000). "Concrete Slabs Reinforced with FRP Grids. II: Punching Resistance." ASCE, Journal of Composites for Constructions, Vol. 4, No. 3, August, pp. 154-161.

[13] Ospina, C.E., Alexander, S.D. B., and Roger Cheng, J.J. (2003). "Punching of twoway concrete slabs with fiber-reinforced polymer reinforcing bars or grids." ACI structuralconcrete slabs with fiber-reinforced polymer reinforcing bars or grids." ACI structural Journal, Vol. 100, No. 5, September-October, pp. 589-598.

[14] Ilker Fatih Kara and Besian Sinani (2017). "Prediction of Punching Shear Capacity of Two-Ways FRP Reinforced Concrete Slabs." International Journal of Business and Technology: Vol. 5 : Iss. 2, Article 3. DOI:10.33107/ijbte.2017.5.2.03, Available at: https://knowledgecenter.ubt-uni.net/ijbte/vol5/iss2/3. 
[15] Zaghloul, A.E.R., Razaqpur, A.G. (2004), "Punching Shear Strength of Concrete Flat Plates Reinforced with CFRP Grids', 4th International Conference on Advanced Composite Materials in Bridges and Structures, Calagary, Alberta, July 20-23, 2004.

[16] ASTM D7205 / D7205M-06, Standard Test Method for Tensile Properties of Fiber Reinforced Polymer Matrix Composite Bars, (2011).

[17] Josef Hegger, Marcus Ricker and Alaa G. Sherif (2009). "Punching Strength of Reinforced Concrete Footings." ACI Structural Journal, V. 106, No. 5, SeptemberOctober 2009.

[18] Ahmed El-Sayed, Ehab El-Salakawy and Brahim Benmokrane (2005). "Shear Strength of One-Way Concrete Slabs Reinforced with Fiber-Reinforced Polymer Composite Bars." Journal of Composites for Construction, Vol. 9, No. 2, April 1, 2005, DOI: 10.1061/(ASCE)1090-0268(2005)9:2(147). 